\title{
Natural gas genesis and sources in the Zizhou gas field, Ordos Basin, China
}

\author{
Shipeng Huang*, Xiang Fang, Dan Liu, Chenchen Fang, Tongfei Huang \\ Research Institute of Petroleum Exploration \& Development, PetroChina, Beijing, 100083 \\ *Corresponding author: shipenghuang@petrochina.com.cn
}

\begin{abstract}
The Zizhou gas field is a large, tight sandstone gas field in the Ordos Basin, China. Based on the analysis of the geological background, gas components, light hydrocarbon composition, carbon and hydrogen isotope values of alkane gases, and the geochemical correlation between gases of the Zizhou gas field and analogues from other fields in the basin, we conclude that : (a) most natural gases in the Zizhou gas field are dry with a small content of wet gas; (b) the gases have similar carbon isotopic and light hydrocarbon compositions to the analogues from other fields, as well as much more positive $\delta^{13} \mathrm{C}$ values and high contents of $\mathrm{C}_{5-7} i$-alkanes and methylcyclohexanes, indicating typical coal-derived gas; (c) carbon isotopic reversal in some gas samples is due to mixing of coal-derived gases of different maturities; (d) the gases are sourced from mature to high-mature Carboniferous-Permian coal-measures; and (e) the gas reservoirs represent continuous accumulations.
\end{abstract}

Key words: Carbon and hydrogen isotope values, Light hydrocarbon, Coal-derived gas, Carboniferous-Permian, Zizhou gas field, Ordos Basin

\section{Introduction}

The Ordos Basin in central China, covering an area of $25 \times 10^{4} \mathrm{~km}^{2}$, is the second largest sedimentary basin in China and an important petroliferous basin. The Paleozoic and the Mesozoic formations of the basin generate distinct gas and oil fields with gas fields mainly located in the northern basin (Fig. 1) and oil fields in the southern basin; oil reservoirs are mainly located in the shallow zone and gas reservoirs in the deep zone (Dai et al., 2005). Six gas fields (Sulige, Jingbian, Da'niudi, Wushenqi, Yulin and Zizhou) with proven gas reserves of over 100 billion cubic meters and three gas fields (Shenmu, Mizhi and Liuyangbao) with proven gas reserves of over 30 billion cubic meters were discovered in the basin. Except for the natural gases preserved in dolomite reservoirs of the Lower Ordovician Majiagou Formation in Jingbian gas field, gases of other fields are mainly preserved in the Carboniferous-Permian sandstone reservoirs.

The Zizhou gas field is located in the east of the Ordos Basin and extends in a NW-SE direction (Fig. 1). In 2011, its proven gas reserves were booked to be $115.2 \times 10^{9} \mathrm{~m}^{3}$ with annual gas production of $10.52 \times 10^{8} \mathrm{~m}^{3}$ from subaqueous distributary channel sands of the lower Permian Shanxi Formation and the middle Permian Lower Shihezi Formation, as well as limestone of the mower Permian Taiyuan Formation (Figs. 1b, c and d). Measurements from 1028 samples from 
the Shanxi and Lower Shihezi formations in the Zizhou gas field, have an average porosity of 5.3 vol. $\%$ and permeability ranges from $0.004 \times 10^{-3} \mu^{2}$ to $232.884 \times 10^{-3} \mu \mathrm{m}^{2}$, with an average of $3.498 \times 10^{-3} \mu \mathrm{m}^{2}$ (Dai et al., 2012a), indicating a tight sandstone gas field. Geochemical features and genesis of Paleozoic gases in the Ordos Basin are well described (Yang and Pei, 1996; Dai et al., 2002, 2003, 2005, 2012a; Mi et al., 2007; Zou et al., 2007; Hu et al., 2010), but the genesis and sources of natural gases in the Zizhou gas field (including geochemical and isotopic data) are largely unpublished. This paper discusses natural gas genesis and sources in the Zizhou gas field based on the analysis of carbon and hydrogen isotope values of gas components, light hydrocarbon composition, and geochemical correlation between the Zizhou gases and analogues from other fields in the Ordos Basin. The study of this paper is believed to be of theoretical and practical significance to the study of the Paleozoic gas accumulation process in the Ordos Basin.

\section{Geological setting}

The Ordos Basin is a stably-depressed multi-cycle cratonic basin with shifted depressions and obvious twist and tilts towards the southwest; the internal basin is of low relief (Yang and Pei, 1996). Natural gases mainly concentrate in the Yishaan Slope in the central basin.

The sedimentary strata in the Ordos Basin are 5000 m thick on average; Silurian and Devonian sediments are missing. The middle and upper Proterozoic systems comprise marine and continental rift sediments with thickness of 200-3000 m. The lower Paleozoic system consists of 400-1600 m of marine carbonate rocks (Fig. 2) and the upper Paleozoic system mainly consists of 600-1700 m of fluvial and swamp sediments (Fig. 2). The Cenozoic system is usually $300 \mathrm{~m}$ thick in the internal basin (Yang and Pei, 1996). There are two sets of Paleozoic petroleum systems in the Ordos Basin (Dai et al., 2005). The lower Paleozoic system is composed of upper source rocks of Carboniferous-Permian coal-measure mudstone and coals, and lower reservoir rocks of Ordovician Majiagou dolomite. The other is a self-sourced and self-preserved upper Paleozoic system composed of Carboniferous-Permian coal and mudstone source rocks and sandstone reservoir rocks (Dai et al., 2003, 2005; Zou et al., 2007).

Gas reservoirs in the Zizhou gas field occur in the eighth member of the Lower Shihezi Formation (He8 Member), the second member of the Shanxi Formation (Shan2 Member) and the Taiyuan Formation. Shan 2 and He8 reservoir rocks are subaqueous distributary channel sands with low porosity and low permeability, which pinch out and merge into argillaceous sediments of inter-distributary bay facies as the lateral barriers for gas reservoirs (Figs. 1b and 1c). The Permian Upper Shihezi Formation is composed of shore to shallow lacustrine sediments and cumulative mudstone, as the regional overburden of upper Paleozoic gas reservoir, and is about 70-110 m thick, accounting for $80 \%$ of total thickness of this formation (Dai et al., 2003). Mudstones inside 
the Shanxi and Lower Shihezi formations, and coal seams in the Shanxi and Taiyuan formations, act as the immediate overburden cap rock of the gas reservoirs (Fig. 1c). The overlying upper Triassic oil source rocks extending over $9 \times 10^{4} \mathrm{~km}^{2}$ also have good regional sealing performance (Wang, 2002).

Taiyuan Formation gases in the nose-like uplift (Fig. 1d) accumulate in tight bioclastic limestone with the matrix porosity less than $1 \%$ and permeability of $(0.01-0.05) \times 10^{-3} \mu^{2}$ (Dai et al., 2003). Fractures have played an important role in natural gas preservation, migration, and recovery in this kind of reservoir. The limestone has a lenticular shape with a maximum thickness of $25 \mathrm{~m}$ (Dai et al., 2005), pinching out to the eastern and western sides, and transforming into dark mudstone forming lithologic traps.

\section{Analytical methods}

A total of 17 gas samples were taken from the Zizhou gas field. Chemical and stable isotopes (C-H) were analyzed at the Research Institute of Petroleum Exploration and Development (Langfang Branch), PetroChina, according to the methods as described by Dai et al. (2012b, 2014). The results are shown in Tables 1 and 2. Moreover, other 48 gas samples were taken in the Ordos Basin for acquiring geochemical data (Tables 3 to 5), and their chemical and isotopic compositions were analyzed using the same methods and laboratory. Consequently, all the data in this paper are comparable. Geochemical parameters of light hydrocarbons in the gases of the Zizhou gas field are presented in Table 6 .

\subsection{Chemical composition analysis}

An Agilent 6890N gas chromatograph (GC) equipped with a flame ionization detector and a thermal conductivity detector were used to determine the chemical composition of gas samples. The hydrocarbon gas components were separated using a capillary column (PLOT $\mathrm{Al}_{2} \mathrm{O}_{3} 50 \mathrm{~m} \times$ $0.53 \mathrm{~mm}$ ). The $\mathrm{GC}$ oven temperature was initially set at $30^{\circ} \mathrm{C}$ for $10 \mathrm{~min}$, and then ramped up to the maximum (i.e. $180^{\circ} \mathrm{C}$ ) at a rate of $10^{\circ} \mathrm{C} / \mathrm{min}$ and maintained for $20-30 \mathrm{~min}$.

\subsection{Stable carbon and hydrogen isotopic analysis}

Many studies of natural gas carbon isotopic composition are well established (Cavanagh and Watters, 2004; Brand, 2014), but previous international reference materials are nearly exhausted after many years of distribution. Because of the lack of natural gas hydrogen isotope reference materials, hydrogen isotopic values determined by different laboratories have very poor repeatability and cannot be compared with each other. New reference materials for natural gas carbon and hydrogen isotopic compositions should be established. International standard gas samples NG1 (coal-related gas), NG2 (biogas), and NG3 (oil-related gas), which were 
co-developed by the Gas Accumulation and Development Laboratory, PetroChina Research Institute of Petroleum Exploration and Development (Langfang Branch), China, and foreign renowned laboratories from USA and Germany (Dai et al., 2012c), were used for the carbon and hydrogen isotope ratio analysis. The calibrated consensus values of the NG1, NG2, and NG3 are:

NG1 (coal-related gas):

Methane: $\delta^{13} \mathrm{C}_{\mathrm{VPDB}}=-34.18 \%$ $\pm 0.10 \%, \delta^{2} \mathrm{H}_{\mathrm{VSMOW}}=-185.1 \%$ $\pm 1.2 \%$

Ethane: $\delta^{13} \mathrm{C}_{\mathrm{VPDB}}=-24.66 \% \pm \pm 0.11 \%$, $\delta^{2} \mathrm{H}_{\mathrm{VSMOW}}=-156.3 \%$ $\pm 1.8 \%$

Propane: $\delta^{13} \mathrm{C}_{\mathrm{VPDB}}=-22.21 \% \mathrm{0} \pm 0.11 \%, \delta^{2} \mathrm{H}_{\mathrm{VSMOW}}=-143.6 \% \pm \pm 3.3 \%$

$i$-Butane: $\delta^{13} \mathrm{C}_{\mathrm{VPDB}}=-21.62 \% \pm \pm 0.12 \%$

$n$-Butane: $\delta^{13} \mathrm{C}_{\mathrm{VPDB}}=-21.74 \%$ o $\pm 0.13 \%$

$\mathrm{CO}_{2}: \delta^{13} \mathrm{C}_{\mathrm{VPDB}}=-5.00 \%$ o $\pm 0.12 \%$

NG2 (biogas):

Methane: $\delta^{13} \mathrm{C}_{\mathrm{VPDB}}=-68.89 \% \pm \pm 0.12 \%, \delta^{2} \mathrm{H}_{\mathrm{VSMOW}}=-237.0 \% \mathrm{0} \pm 1.2 \%$

NG3 (oil-related gas):

Methane: $\delta^{13} \mathrm{C}_{\mathrm{VPDB}}=-43.61 \% \mathrm{0} \pm 0.09 \%, \delta^{2} \mathrm{H}_{\mathrm{VSMOW}}=-167.6 \% \pm \pm 1.0 \%$

Ethane: $\delta^{13} \mathrm{C}_{\mathrm{VPDB}}=-40.24 \% \pm \pm 0.10 \%, \delta^{2} \mathrm{H}_{\mathrm{VSMOW}}=-164.1 \%$ $\pm 2.4 \%$

Propane: $\delta^{13} \mathrm{C}_{\mathrm{VPDB}}=-33.79 \%$ o $\pm 0.09 \%, \delta^{2} \mathrm{H}_{\mathrm{VSMOW}}=-138.4 \%$ $\pm 3.0 \%$

On-line measurement was used for natural gas carbon and hydrogen isotopic compositions. The stable carbon and hydrogen isotope values are reported in " $\delta$ " notation in per mil (\%). The $\delta^{13} \mathrm{C}$ and $\delta^{2} \mathrm{H}$ values were measured and expressed relative to the VPDB (Vienna PDB), and VSMOW (Vienna SMOW) scale, respectively. A 2-point calibration was used in the measurement of the hydrogen stable isotope ratios. The measurement tolerances of carbon and hydrogen isotope values are $\pm 0.3 \%$ and $\pm 3 \%$, respectively. Specific procedures of the measurement are as follows:

Stable carbon isotope ratios were determined on a Finnigan Mat Delta S mass spectrometer interfaced with a HP 5890II chromatograph. Gas components were separated on the gas chromatograph in a stream of helium, converted into carbon dioxide in a combustion interface and then introduced into the mass spectrometer. Alkane gases $\left(\mathrm{C}_{1}-\mathrm{C}_{4}\right)$ and carbon dioxide were initially separated using a fused silica capillary column (PLOT $30 \mathrm{~m} \times 0.32 \mathrm{~mm}$ ). The GC oven temperature was ramped up from $35-80^{\circ} \mathrm{C}$ at $8^{\circ} \mathrm{C} / \mathrm{min}$, then to $260^{\circ} \mathrm{C}$ at $5^{\circ} \mathrm{C} / \mathrm{min}$, and finally maintained at its final level for $10 \mathrm{~min}$. Gas samples were analyzed three times and averaged.

Hydrogen isotope values of gases were determined on a MAT253 isotopic mass spectrometer (Thermo Fisher Scientific) equipped with a Trace GC UltraTM using the gas chromatography pyrolysis interface and the water removal device. Helium was used as the stream gas, and a HP-PLOT Q column $(30 \mathrm{~m} \times 0.32 \mathrm{~mm} \times 20 \mu \mathrm{m})$ was used with flow rate $1.4 \mathrm{ml} / \mathrm{min}$. The inlet 
temperature was set at $180^{\circ} \mathrm{C}$. The $\delta^{2} \mathrm{H}$ values of methane were determined in split injection mode (split ratio 1:7). The temperature was initially set at $40^{\circ} \mathrm{C}$ and maintained for $5 \mathrm{~min}$, then ramped up to $40-80^{\circ} \mathrm{C}$ at rate of $5^{\circ} \mathrm{C} / \mathrm{min}, 80-140^{\circ} \mathrm{C}$ at $10^{\circ} \mathrm{C} / \mathrm{min}$ and $140-260^{\circ} \mathrm{C}$ at $30^{\circ} \mathrm{C} / \mathrm{min}$. The pyrolysis oven temperature was $1450^{\circ} \mathrm{C}$. Hydrocarbons were transformed into $\mathrm{C}$ and $\mathrm{H}_{2}$, with $\mathrm{H}_{2}$ measured in the mass spectrometer.

\subsection{Light hydrocarbon analysis}

Light hydrocarbons were analyzed on a HP5890A GC with an HP PONA capillary column (50 $\mathrm{m} \times 0.25 \mathrm{~mm} \times 0.25 \mu \mathrm{m})$. The initial temperature was $120{ }^{\circ} \mathrm{C}$ with helium as the carrier gas. The components were collected with a liquid nitrogen cold trap for $5 \mathrm{~min}$, and the eluting hydrocarbons were detected using an FID at a temperature of $320{ }^{\circ} \mathrm{C}$. The initial oven temperature was maintained at $25{ }^{\circ} \mathrm{C}$ for $15 \mathrm{~min}$, ramped up to $70{ }^{\circ} \mathrm{C}$ at a rate of $1.5{ }^{\circ} \mathrm{C} / \mathrm{min}$ and then to $160{ }^{\circ} \mathrm{C}$ at $3{ }^{\circ} \mathrm{C} / \mathrm{min}$; finally the temperature increased from $160{ }^{\circ} \mathrm{C}$ to $270{ }^{\circ} \mathrm{C}$ at a rate of $5{ }^{\circ} \mathrm{C}$ $/ \mathrm{min}$. The final temperature was maintained for $20 \mathrm{~min}$.

Light hydrocarbon was qualitatively analyzed using an Agilent PONA gas chromatograph. The standard test mixture contained 53 compounds (from $i$-butane to normal octane). The compounds were quantified by peak area of individual compound. Light hydrocarbon analysis of the test mixture was carried out before the analysis of the study samples in order to guarantee sample analysis quality and comparability of analytical samples at different times.

\section{Results}

\subsection{Natural gas components}

Natural gas components in the Zizhou gas field are shown in Table 1 and alkane gases are dominant. Content of the components is expressed in vol. \%. Specially, methane content is 90.44-95.35\%, with an average of $93.52 \%$; ethane content is $2.69-5.42 \%$, with an average of $3.72 \%$; propane content is $0.16-1.54 \%$, with an average of $0.65 \%$; isobutane content ranges in $0.05-0.31 \%$, with an average of $0.12 \%$; and $n$-butane content ranges in $0.04-0.34 \%$, with an average of $0.12 \%$. The gas dry coefficient $\left(\mathrm{C}_{1} / \mathrm{C}_{1-4}\right)$ lies between 0.922 and 0.968 , with an average of 0.953 , indicating that gases are mainly dry gas with high maturity. Non-hydrocarbon gases include $\mathrm{CO}_{2}$ and $\mathrm{N}_{2}$, with $\mathrm{CO}_{2}$ content generally higher than $\mathrm{N}_{2} \cdot \mathrm{CO}_{2}$ content is in the range of $0.50-1.93 \%$, with an average of $1.29 \%$, and $\mathrm{N}_{2}$ content is $0.23-1.48 \%$, with an average of $0.48 \%$.

\subsection{Carbon and hydrogen isotopic compositions}

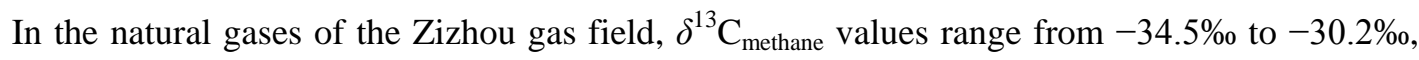
with an average of $-32.5 \%$; $\delta^{13} \mathrm{C}_{\text {ethane }}$ values range from $-26.3 \%$ to $-22.7 \%$, with an average of 
$-24.7 \%$; $\delta^{13} \mathrm{C}_{\text {propane }}$ values range from $-25.2 \%$ to $-21.7 \%$, with an average of $-23.2 \%$; and $\delta^{13} \mathrm{C}_{\text {butane }}$ values range from $-23.3 \%$ to $-19.4 \%$, with an average of $-22.2 \%$ (Tables 1 and 2 ). These indicate that the maximum, minimum, and mean carbon isotope values of methane, and any of its homologues increase as the carbon number increases.

As per the hydrogen isotope measurements of alkane gases in 6 gas samples, $\delta^{2} \mathrm{H}_{\text {methane values }}$ range from $-185 \%$ to $-179 \%$, with an average of $-182 \%$; $\delta^{2} \mathrm{H}_{\text {ethane }}$ values range from $-165 \%$ to $-161 \%$, with an average of $-163 \%$, and $\delta^{2} \mathrm{H}_{\text {propane }}$ values range from $-157 \%$ to $-151 \%$, with an average of $-154 \%$. These indicate that the maximum, minimum, and mean hydrogen isotope values of methane, and any of its homologues increase as the carbon number increases, which is consistent with the trend of carbon isotopes. In view of the measurements of each sample, the carbon and hydrogen isotopic constitutions increase with carbon number, except in gas samples from individual wells which show some opposite trends of ethane and propane carbon isotope values. In other words, carbon isotopes $\left(\delta^{13} \mathrm{C}_{1}<\delta^{13} \mathrm{C}_{2}<\delta^{13} \mathrm{C}_{3}<\delta^{13} \mathrm{C}_{4}\right)$ (Fig. 3) and hydrogen isotopes $\left(\delta^{2} \mathrm{H}_{1}<\delta^{2} \mathrm{H}_{2}<\delta^{2} \mathrm{H}_{3}<\delta^{2} \mathrm{H}_{4}\right)$ all demonstrate positive sequences, indicating that the natural gases are primary gas (Fig. 4).

\subsection{Light hydrocarbon composition}

Light hydrocarbon composition and relevant parameters are shown in Table 6. Heptane and isoheptane values are $10.9-12.9 \%$ and $2.1-4.0 \%$, respectively. In total $\mathrm{C}_{5-7}$ compounds, $\mathrm{C}_{5-7}$ $n$-alkanes only account for $19.8-22.5 \%$ with an average content of $21.2 \%$; $\mathrm{C}_{5-7} i$-alkanes account for $40.9-51.7 \%$ of the total $\mathrm{C}_{5-7}$ compounds, and the average value is $46.1 \%$; and $\mathrm{C}_{5-7}$ cyclic alkanes are $27.3-39.3 \%$, with an average of $33.4 \%$ (Fig. 5). In the relative composition of normal heptane, methylcyclohexane and dimethyl cyclopentane (Fig. 6), methylcyclohexane is dominant, $67.6-71.6 \%$, with an average content of $69.2 \%$; normal heptane accounts for $14.4-15.7 \%$, with a small average value of $15.0 \%$, and dimethyl cyclopentane accounts for $12.7-17.6 \%$, with an average of $15.8 \%$.

\section{Discussion}

\subsection{Natural gas genesis}

Organic alkane gas has positive sequences of carbon and hydrogen isotope values (Clayton, 1991; Dai et al., 1992, 2004; Mani et al., 2011). Most alkane gases in the Zizhou gas field were identified to be of thermogenic origin, according to their positive sequences of carbon and hydrogen isotope values. Line charts of carbon and hydrogen isotopes are very consistent, indicating that they originate from the same source.

The line connecting data points of methane and its homologues would be a straight line in the 
$\delta^{13} \mathrm{C}-1 / \mathrm{C}_{\mathrm{n}}$ plot if they were derived from the same source rock, and be concave up or down if they are derived from different source rocks (Chung et al., 1988). Thus, according to the thermal simulation for oil-prone and gas-prone source rocks, natural gases generated in mature source rocks all correspond to straight lines in the $\delta^{13} \mathrm{C}-1 / \mathrm{C}_{\mathrm{n}}$ chart, but gases generated in post-mature oil-prone source rocks have a concave-down curve, and the analogue generated in post-mature gas-prone source rocks has a concave-up curve (Zou et al., 2007). The upper Paleozoic Permian alkane gases from the Zizhou, Yulin, Sulige, and Jingbian gas fields generally demonstrate a concave-up geometry in the isotopic line chart (Fig. 3), indicating that they mostly originate in gas-prone source rocks, i.e. humic source rocks. Some lower Paleozoic Majiagou gas samples from Jingbian gas field show a concave-down geometry (Fig. 3d), denoting a mixture of some oil-associated gas.

The ethane carbon isotope value is a significant indicator most commonly used to differentiate coal-derived gas from oil-associated gas (Dai et al., 2005). In general, the value in a coal-derived gas has distinct values above $-28 \%$ (Xu and Shen, 1996; Dai et al., 1992; Liu et al., 2008, 2011; Dai, 2011; Wang et al., 2013). Natural gases in the Zizhou gas field typically show features of coal-derived gas because their ethane carbon isotope values range from $-26.3 \%$ to $-22.7 \%$, all greater than $-28 \%$. On the $\delta^{13} \mathrm{C}_{1}-\delta^{13} \mathrm{C}_{2}-\delta^{13} \mathrm{C}_{3}$ plot for natural gas genesis identification (Dai et al., 2014) (Fig. 7), gas points from the Zizhou gas field are all within the region of coal-derived gas, similar to Permian gases from Yulin, Sulige and Jingbian gas fields. Some Majiagou gas points from Jingbian gas field fall into the region of oil-associated gas.

On the $\delta^{13} \mathrm{C}_{1}-\delta^{13} \mathrm{C}_{2}$ plot (Fig. 8), the Zizhou gas samples distribute in a similar trend to the analogues of Type-III kerogen from the Niger Delta and the Sacramento Basin, which is clearly different from the trend for samples of Type-II kerogen from the Delaware/Val Verde basins. Ordovician Majiagou gases in Jingbian gas field differ greatly from Permian gases in other fields, which indicate different gas types and origins of the two reservoirs.

The plot of $\delta^{13} \mathrm{C}_{1}-\mathrm{C}_{1} /\left(\mathrm{C}_{2}+\mathrm{C}_{3}\right)$ (Fig. 9) is widely used to identify kerogen types for gas generation (Whiticar, 1999). The Zizhou gases, as well as Permian gases from Yulin, Sulige, and Jingbian gas fields, were yielded from Type-III kerogen, and all belong to coal-derived gas. The Ordovician Majiagou gases in Jingbian gas field are within were yielded from kerogens between type-II and type-III, and belong to mixed sapropelic and humic gases.

Thompson (1983) proposed that the correlation between heptane and isoheptane values could be used to identify natural gas types. Fig. 10 shows the Zizhou gas points distributed at the margin of the high-mature zone, similar to the aromatic series generated by humic organic matter and indicates that the Zizhou gases originate in humic source rocks with high maturity. 
Hu et al. (1990) made a template for natural gas identification based on the triangular plot of $\mathrm{C}_{5-7} n$-alkanes, $i$-alkanes, and cyclic alkanes in Jurassic to Triassic Jialingjiang gases in the Sichuan Basin (Fig. 5); the Zizhou gas points fall into the region of coal-derived gas. Sapropelic kerogen-originated light hydrocarbon components are rich in $n$-alkanes, and humic kerogen -originated light components are rich in $i$-alkanes and aromatic hydrocarbons (Leythaeuser et al., 1979a, b). C 7 light hydrocarbon components (normal heptane, methylcyclohexane, and dimethyl cyclopentanes with different chemical constitutions) may indicate natural gas type (Dai et al., 1992) and also shows that the Zizhou gases belong to coal-derived gases (Fig. 6).

Stable carbon and hydrogen isotope values together with light hydrocarbon components, show that natural gases in the Zizhou gas field are typical coal-derived gases.

\subsection{Natural gas maturity}

Natural gas maturity is closely related to gas-source correlation. The maturity of gas source rocks could be estimated with the methane carbon isotope values, based on some $\delta^{13} C_{1}-R_{o}$ empirically derived equations (Stahl and Carey, 1975; Dai and Qi, 1989; Shen et al., 1991; Liu and $\mathrm{Xu}, 1999$ ), as shown in Table 1. The equations proposed by Stahl and Carey (1975) and Shen et al. (1991) generated lower maturities, whereas those proposed by Dai and Qi (1989) as well as Liu and Xu (1999) generated higher maturities. $\mathrm{R}_{\mathrm{o}}$, based on Dai and Qi (1989), is 0.98-1.98\%, with an average of $1.38 \%$, indicating that most gases are high-mature gases, and the analogue based on Liu and Xu (1999) is 1.03-1.60\%, with an average of $1.27 \%$, indicating the end of the maturity stage. The former is higher than the latter. As per the correlation of $R_{o}$ estimations with actual thermal evolution of source rocks, the equation derived by Dai and Qi (1989), i.e. $\delta^{13} \mathrm{C}_{1}=14.12 \lg \mathrm{R}_{\mathrm{o}}-34.39$, would generate the result reconciled with actual thermal evolution (Dai et al., 2005).

Reversal of carbon isotope values in alkane gases may be caused by (1) mixing of organic alkane gas with inorganic alkane gas, (2) mixing of coal-derived gas with oil-associated gas, (3) mixing of gases of the same type from different sources, or gases from the same source generated in different episodes (Berner and Faber, 1988; James, 1990), (4) bacterial oxidation of a certain or some gas components (James and Burns, 1984), or (5) thermochemical sulfate reduction (TSR) (Dai et al., 2004; Hao et al., 2008). For gases in the Zizhou gas field, factors (1), (2), and (3) are excluded because the alkane gases are all coal-derived gases with organic origin, and reservoirs are composed of sulfate-poor clastic rocks. A bacteria-oxidized natural gas would have a much more positive $\delta^{13} \mathrm{C}$ value with decreased content; the reversed sequence of $\delta^{13} \mathrm{C}_{2}>\delta^{13} \mathrm{C}_{3}$ could be observed in the Zizhou gases, but the ethane content is not lower than the propane content. In addition, Permian gases are buried at a depth of more than $2000 \mathrm{~m}$, where bacterial activities would 
be inhibited (Dai et al., 2004); therefore the factor (4) can also be excluded. The Zizhou gas field contains some mature gases, and high-mature gases; reversed sequence of ethane and propane carbon isotope values are also observed for some wells (Zhou4, Yu30 and Yu 44-01) in the range of $0.4 \%$ to $1.1 \%$, which may be due to the mixture of coal-derived gases of different episodes.

The alkane gas hydrogen isotope value is dependent on source rock type, maturity, and aquatic depositional environment for source rocks (Schoell, 1980; Whiticar, 1999; Clayton., 2003; Liu et al., 2008; Kotarba and Lewan, 2013). Hydrogen isotope values positively correlate with maturity and increase with maturity. As discussed above, gases in the Zizhou gas field and Permian gases in Sulige gas field have similar origins, but the hydrogen isotope values of alkane gas in the latter is enriched in ${ }^{2} \mathrm{H}$ compared to in the former, which indicates that the maturities of the gases in Sulige gas field is higher than those in the Zizhou gas field (Fig. 4a and b) which has also been demonstrated by maturity estimation from the methane carbon isotope values (Table 2).

Fig. 11 shows the correlation between natural gas maturities $\left(\mathrm{R}_{\mathrm{o}}\right)$ based on the empirical equation of $\delta^{13} \mathrm{C}_{1}-\mathrm{R}_{\mathrm{o}}$ developed by Dai and Qi (1989), and differences between $\mathrm{C}_{2}-\mathrm{C}_{4}$ hydrocarbon gas carbon isotopes and methane carbon isotopes. The isotopic difference decreases with maturity, denoting the small isotopic fractionation at the later stage of hydrocarbon generation. The Permian gases in Sulige, Yulin, Zizhou, and Jingbian gas fields in the Ordos Basin are mature to high-mature (Fig. 3a, b and c), corresponding to mature to high-mature source rocks, which demonstrates that Permian gas reservoirs belong to continuous accumulations.

\subsection{Natural gas sources}

The extensive Carboniferous-Permian coal measures in the Ordos Basin are generally 10-15 m and locally greater than $40 \mathrm{~m}$ thick; dark mudstone is about $200 \mathrm{~m}$ thick cumulatively, and generally $70 \mathrm{~m}$ thick in the central and eastern basin (Yang and Pei, 1996; Dai et al., 2003, 2005). The total organic carbon (TOC) content of the mudstone is generally $2-4 \mathrm{wt} . \%$, and the average one of the coal can reach $60 \%$. Organic matter is mainly of Type-III. Source rocks are mature to the north of Jingbian-Dingbian-Zizhou, and become post-mature to the south (Dai et al., 2005). For the upper Paleozoic gases in the Ordos Basin, it is widely accepted that natural gases originate in Carboniferous-Permian coal measures (Dai et al., 2003, 2005, 2012; Hu et al., 2010; Huang et al., 2014; Yang and Pei, 1996). Based on the above discussions, it is concluded that natural gases in the Zizhou gas field are also coal-derived gases from mature to high-mature Carboniferous-Permian coal measures.

\section{Conclusions}

(a) Positive carbon isotope $\left(\delta^{13} \mathrm{C}_{1}<\delta^{13} \mathrm{C}_{2}<\delta^{13} \mathrm{C}_{3}<\delta^{13} \mathrm{C}_{4}\right)$ and hydrogen isotope value 
$\left(\delta^{2} \mathrm{H}_{1}<\delta^{2} \mathrm{H}_{2}<\delta^{2} \mathrm{H}_{3}<\delta^{2} \mathrm{H}_{4}\right)$ sequences have been discovered in the natural gases of the Zizhou gas field, indicating that the natural gases are primary.

(b) Carbon isotope values and the $\mathrm{C}_{5-7} i$-alkanes and methylcyclohexanes contents are high in the gases of the Zizhou gas field. Natural gases in the Zizhou field and Permian gases in adjacent Sulige, Yulin, and Jingbian gas fields have similar geochemical features and compositions, indicating similar origin in Carboniferous-Permian coal measures.

(c) Alkane gases in the Zizhou gas field are typical of coal-derived gas generated from mature to high-mature source rocks. Gas reservoirs belong to continuous accumulations.

(d) Carbon isotope reversal, i.e. $\delta^{13} \mathrm{C}_{2}>\delta^{13} \mathrm{C}_{3}$, observed in some alkane gases are due to the mixture of coal-derived gases of different maturities.

\section{Acknowledgments}

We would like to acknowledge Professor Jinxing Dai from RIPED, PetroChina, for his critical and constructive comments, which significantly improved the quality of the manuscript. We are very grateful to the two anonymous reviewers and Prof. Shifeng Dai for their insightful comments and suggestions on an earlier version. The work was financially supported by the PetroChina Petroleum Exploration Major Science and Technology Program "Geochemistry and accumulation mechanisms of coal-derived gas in China" (No. 2014B-0608), and the National Science Foundation Project for Young Scholars of China (No. 41303037).

\section{References}

Berner, U., Faber, E., 1988. Maturity related mixing models for methane, ethane and propane, based on carbon isotopes. Organic Geochemistry 13, 67-72.

Brand, W.A., Coplen, T.B., Vogl, J., Rosner, M., Prohaska, T., 2014. Assessment of international reference materials for isotope-ratio analysis (IUPAC Technical Report). Pure and Applied Chemistry 86 (3), 425-467.

Cavanagh, R.R., Watters Jr., R.L., 2004. U.S. National Institute of Standards and Technology Report of Investigation: Reference Materials 8559, 8560, 8561.8 pp.

Chung, H.M., Gormly, J.R., Squires, R.M., 1988. Origin of gaseous hydrocarbons in subsurface environments: Theoretical considerations of carbon isotope distribution. Chemical Geology 71, 97-103.

Clayton, C.J., 1991. Carbon isotope fractionation during natural gas generation from kerogen. Marine and Petroleum Geology 8, 232-240.

Clayton, C.J., 2003. Hydrogen isotope systematics of thermally generated natural gas. In: $21^{\text {st }}$ international Meeting of Organic Geochemistry, Book Abstract. Part I. Kraków, Poland, pp. 51-52.

Dai, J.X., Qi, H.F., 1989. Relationship of $\delta^{13} \mathrm{C}-\mathrm{R}_{\mathrm{o}}$ of coal-derived gas in China. Chinese Science 
Bulletin 34, 690-692 (In Chinese with English abstract).

Dai, J.X., Pei, X.G., Qi, H.F., 1992. China Natural Gas Geology, Vol.1. Petroleum Industry Press, Beijing: 35-86 (In Chinese).

Dai, J.X., Qin, S.F., Xia, X.Y., 2002. Coal-formed gas resource and large gas fields in the western part of China. Bulletin of Mineralogy, Petrology and Geochemistry 21 (1), 12-21 (In Chinese with English abstract).

Dai, J.X, Chen, J.F., Zhong, N.N., Pang, X.Q., Qin, S.F., 2003. Large Gas Fields and Their Source Rocks in China. Beijing: Science Press 93-126 (In Chinese).

Dai, J.X., Xia, X.Y., Qin, S.F., Zhao, J.Z., 2004. Origins of partially reversed alkane $\delta^{13} \mathrm{C}$ values for biogenic gases in China. Organic Geochemistry 35, 405-411.

Dai, J.X., Li, J., Luo X., Zhang, W.Z., Hu, G.Y., Ma, C.H., Guo, J.M., Ge, S.G., 2005. Stable carbon isotope compositions and source rock geochemistry of the giant gas accumulations in the Ordos Basin, China. Organic Geochemistry 36, 1617-1635.

Dai J.X., 2009. Major developments of coal-formed gas exploration in the last 30 years in China. Petroleum Exploration \& Development 36 (3), 264-279.

Dai J.X., 2011. Significances of the study on carbon isotopes of alkane gases. Natural Gas Industry 31 (2), 1-6.

Dai J.X., Ni, Y.Y., Wu, X.Q., 2012a. Tight gas in China and its significance in exploration and exploitation. Petroleum Exploration and Development 39 (3), 257-264.

Dai, J.X., Ni, Y.Y., Zou, C.N., 2012b. Stable carbon and hydrogen isotopes of natural gases sourced from the Xujiahe Formation in the Sichuan Basin, China. Organic Geochemistry 43 (1): 103-111.

Dai, J,X., Xia, X.Y., Li, Z.S., Coleman, D.D., Dias, R.F., Gao, L., Li, J., Deev, A., Li, J., Dessort, D., Dulerc, D., Li, L.W., Liu, J.Z., Schloemer, S., Zhang, W.L., Ni, Y.Y., Hu, G.Y., Wang, X.B., Tang, Y.C., 2012c. Inter-laboratory calibration of natural gas round robins for $\delta^{2} \mathrm{H}$ and $\delta^{13} \mathrm{C}$ using off-line and on-line techniques. Chemical Geology, 310-311: 49-55.

Dai, J.X., Ni, Y.Y., Hu, G.Y., Huang, S.P., Liao, F.R., Yu, C., Gong, D.Y., Wu, W., 2014. Stable carbon and hydrogen isotopes of gases from the large tight gas fields in China. Science China. Earth Sciences 57 (1): 88-103.

Hao, F., Guo, T.L., Zhu, Y.M., Cai, X.Y., Zou, H.Y., Li, P.P., 2008. Evidence for multiple stages of oil cracking and thermochemical sulfate reduction in the Puguang gas field, Sichuan Basin, China. AAPG Bulletin 92 (5), 611-637.

Hu, T. L., Ge, B. X., Zhang, Y.G., Liu, B., 1990. The development and application of fingerprint parameters for hydrocarbons absorbed by source rocks and light hydrocarbons in natural gas. Experimental Petroleum Geology 12 (4), 375-379 (In Chinese with English abstract).

Hu, G.Y., Li, J., Shan, X.Q., Han, Z.X., 2010. The origin of natural gas and the hydrocarbon charging 
history of the Yulin Gas field in the Ordos Basin, China. International Journal of Coal Geology 81, 381-391.

Hu, G.Y., Zhang, S.C., 2011. Characterization of low molecular weight hydrocarbons in Jingbian gas field and its application to gas sources identification. Energy Exploration \& Exploitation 6 (29), 777-796.

Huang, S.P., Yu, C., Gong, D.Y., Wu, W., Liao, F.R., 2014. Stable carbon isotopic characteristics of alkane gases in tight sandstone gas fields and the gas source in China. Energy Exploration \& Exploitation 32 (1), 75-92.

James, A.T., Burns, B.J., 1984. Microbial alteration of subsurface natural gas accumulations. American Association of Petroleum Geologists Bulletin 68, 957-960.

James, A.T., 1990. Correlation of reservoired gases using the carbon isotopic composition of wet gas components. American Association of Petroleum Geologists Bulletin 74, 1141-1158.

Jenden P. D., Kaplan, I. R., Poreda, R., Craig, H., 1988. Origin of nitrogen-rich natural gases in the California Great Valley: Evidence from helium, carbon and nitrogen isotopic ratios. Geochimica et Cosmochimica Acta 52 (4), 851-861.

Kotarba, M.J., Lewan, M.D., 2013. Sources of natural gases in Middle Cambrian reservoirs in Polish and Lithuanian Baltic Basin as determined by stable isotopes and hydrous pyrolysis of Lower Palaeozoic source rocks. Chemical Geology 345, 62-76.

Leythaeuser D., Schaefer, R.G., Weiner, B., 1979a. Generation of low molecular weight hydrocarbons from organic matter in source beds as a function of temperature and faces. Chemical Geology 25, 95-108.

Leythaeuser, D., Schaefer, R. G., Conford, C., Weiner, B., 1979b. Generation and migration of light hydrocarbons $\left(\mathrm{C}_{2}-\mathrm{C}_{7}\right)$ in sedimentary basins. Organic Geochemistry 1, 191-204.

Liu, W.H, Xu, Y.C., 1999. A two-stage model of carbon isotopic fractionation in coal-gas. Geochimica 18 (4), 359-366 (In Chinese with English abstract).

Liu, Q.Y., Dai, J.X., Li, J., Zhou, Q.H., 2008. Hydrogen isotope composition of natural gas from Tarim basin and its suggestion to deposited environments for source rocks. Science in China (Series B) 51 (2) , 300-311.

Liu, Q.Y., Zhang, T.W., Jin, Z.J., Qin, S.F., Tang, Y.C., Liu, W.H., 2011. Kinetic model of gaseous alkanes formed from coal in a confined system and its application to gas filling history in Kuqa depression, Tarim basin, Northwest China. Acta Geologica Sinica 85 (4), 911-922.

Mani, D., Patil, D.J., Dayal, A.M., 2011. Stable carbon isotope geochemistry of adsorbed alkane gases in near-surface soils of the Saurashtra Basin, India. Chemical Geology 280, 144-153.

Mi, J.K., Dai, J.X., Zhang, S.C., Zhang, W.Z., Gong, S, Li X.Q., 2007. Natural gas components and stable isotopes in the fluid inclusions of upper Paleozoic reservoirs in Ordos Basin. Science in 
China Series D (Earth Science) 37 (Suppl. II), 97-103.

Rooney, M.A., Claypool, G.E., Chung, H.M., Moses, H., 1995.Modeling thermogenic gas generation using carbon isotopic ratios of natural gas hydrocarbons. Chemical Geology 126 (3-4), 219-232.

Schoell, M., 1980.The hydrogen and carbon isotopic composition of methane from natural gases of various origins. Geochimica et Cosmochimica Acta 44, 649-661.

Shen, P., Xu, Y.C., Wang, X.B., Liu, D.H., Shen, Q.X., Liu, W.H., 1991. Geochemical characteristics of gas source rocks and natural gas genesis. Gansu Science and Technology Press, Lanzhou, 248 (In Chinese)

Stahl, W. J, Carey, B.D., 1975. Source-rock identification by isotope analyses of natural gases from fields in the Val Verde and Delaware basins, West Texas. Chemical Geology 16, 257-267.

Thompson, K.F.M., 1983. Classification and thermal history of petroleum based on light hydrocarbons. Geochimica et Cosmochimica Acta 47 (2), 303-316.

Wang, T., 2002. Deep Gas in China. Beijing: Petroleum Industry Press, 115-119.

Wang, Z.C., Huang, S.P., Gong, D.Y., Wu, W., Yu, C., 2013. Geochemical characteristics of natural gases in the upper Triassic Xujiahe Formation in the southern Sichuan Basin, SW China. International Journal of Coal Geology 120, 15-23.

Whiticar, M.J, 1999. Carbon and hydrogen isotope systematics of bacterial formation and oxidation of methane. Chemical Geology 161, 291-314.

Xu, Y.C., Shen, P., 1996. A study of natural gas origins in China. AAPG Bulletin 80 (10), 1604-1614.

Yang, Y., Zhou W., Xu C.Y., Hou, W., 2010. Research of aquifer distribution in Shan 2 reservoir of Zizhou gas field. Journal of Daqing Petroleum Institute, 34 (3), 14-18, 39 (In Chinese with English abstract).

Yang, J.J., 2002. Tectonic revolution and petroleum distribution law of the Ordos basin. Beijing: Petroleum Industry Press, 148-156.

Yang, J.J., Pei, X.G., 1996. Natural Gas Geology in China (Vol. 4 Ordos Basin). Beijing: Petroleum Industry Press, 107-112.

Yu, C., Huang, S.P., Gong, D.Y., Liao, F.R., Li J., Sun, Q.W., 2013. Partial reversal cause of carbon and hydrogen isotope compositions of natural gas: a case study in Sulige gas field, Ordos Basin. Acta Petrolei Sinica 34 (Suppl.1), 92-101 (In Chinese with English abstract).

Zou, C.N., Tao, S.Z., 2007. Geological characteristics of large gas provinces and gas fields in China. Science in China Series D 37 (Suppl. II), 12-38.

Zou, Y.R., Cai, Y.L., Zhang, C.C., Zhang, X, Peng, P.A., 2007.Variations of natural gas carbon isotope-type curves and their interpretation-A case study. Organic Geochemistry 38, 1398-1415. 


\section{Clean Figures}
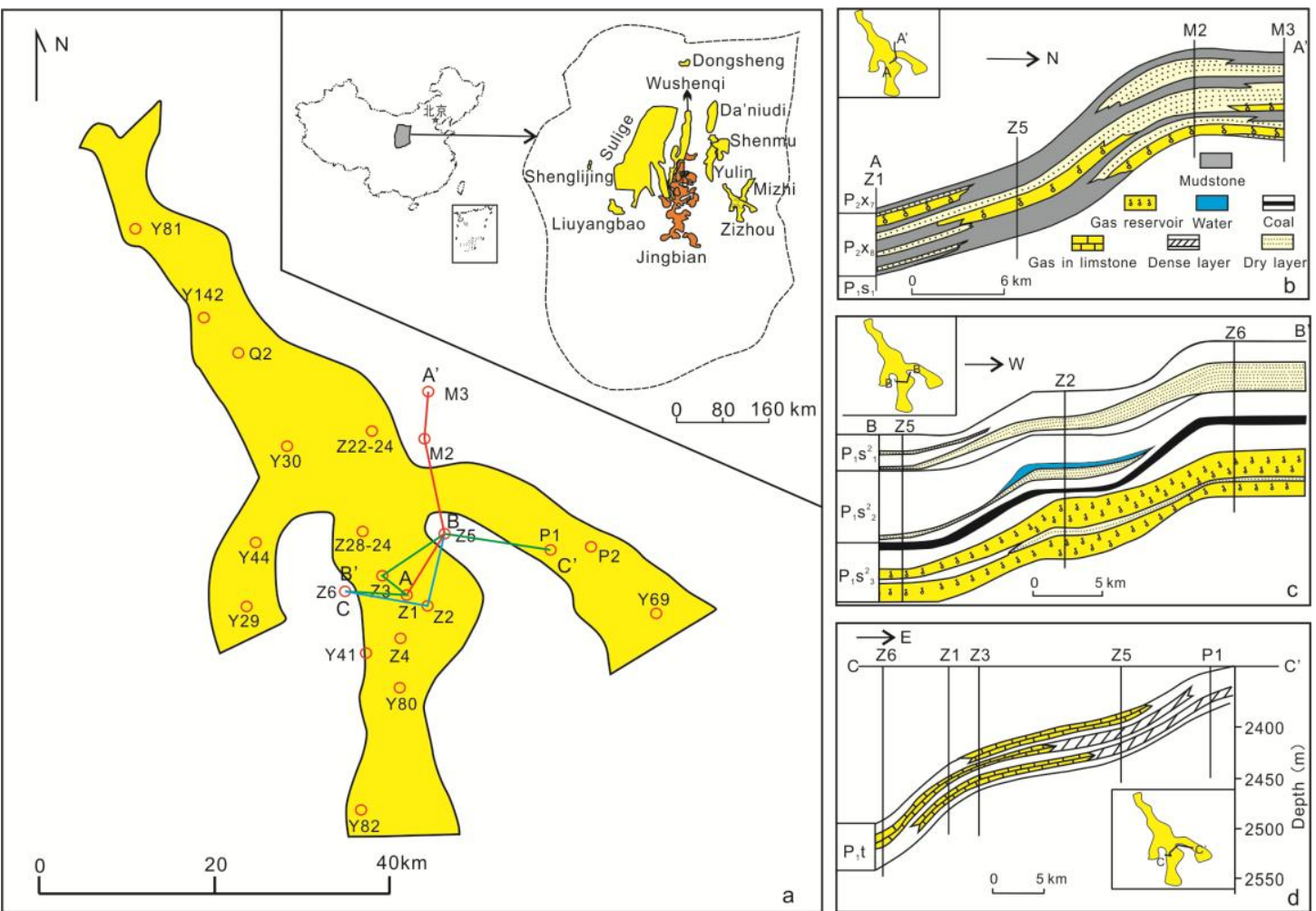

Fig.1 Distribution of the Zizhou gas field (a) and gas reservoir sections (b, $c$ and d) (section b after Dai et al., 2002; c after Yang et al., 2010 and d after Yang, 2002) 


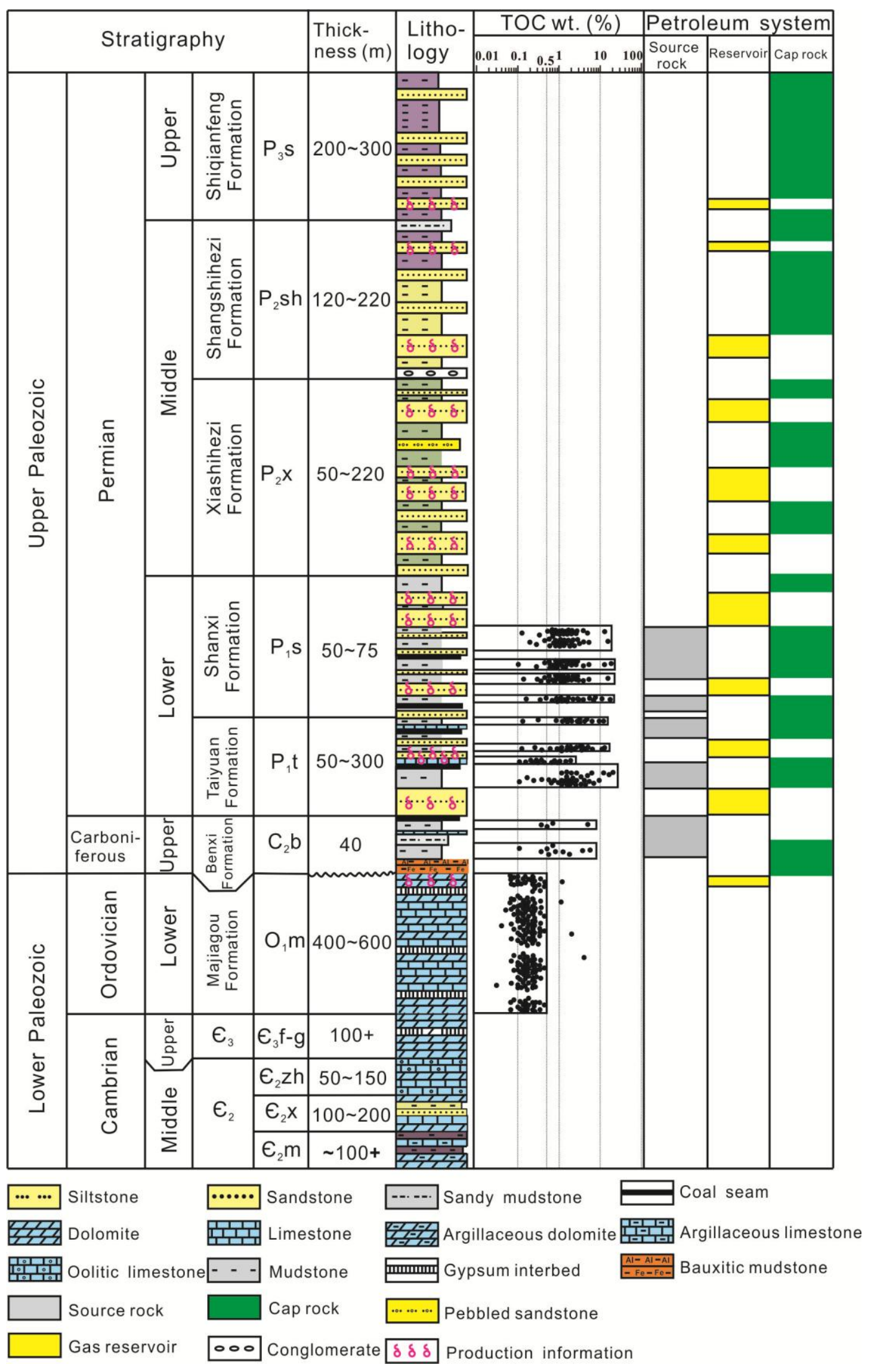

Fig.2 Generalized Paleozoic stratigraphic column for the Ordos Basin (modified from Dai et al., 

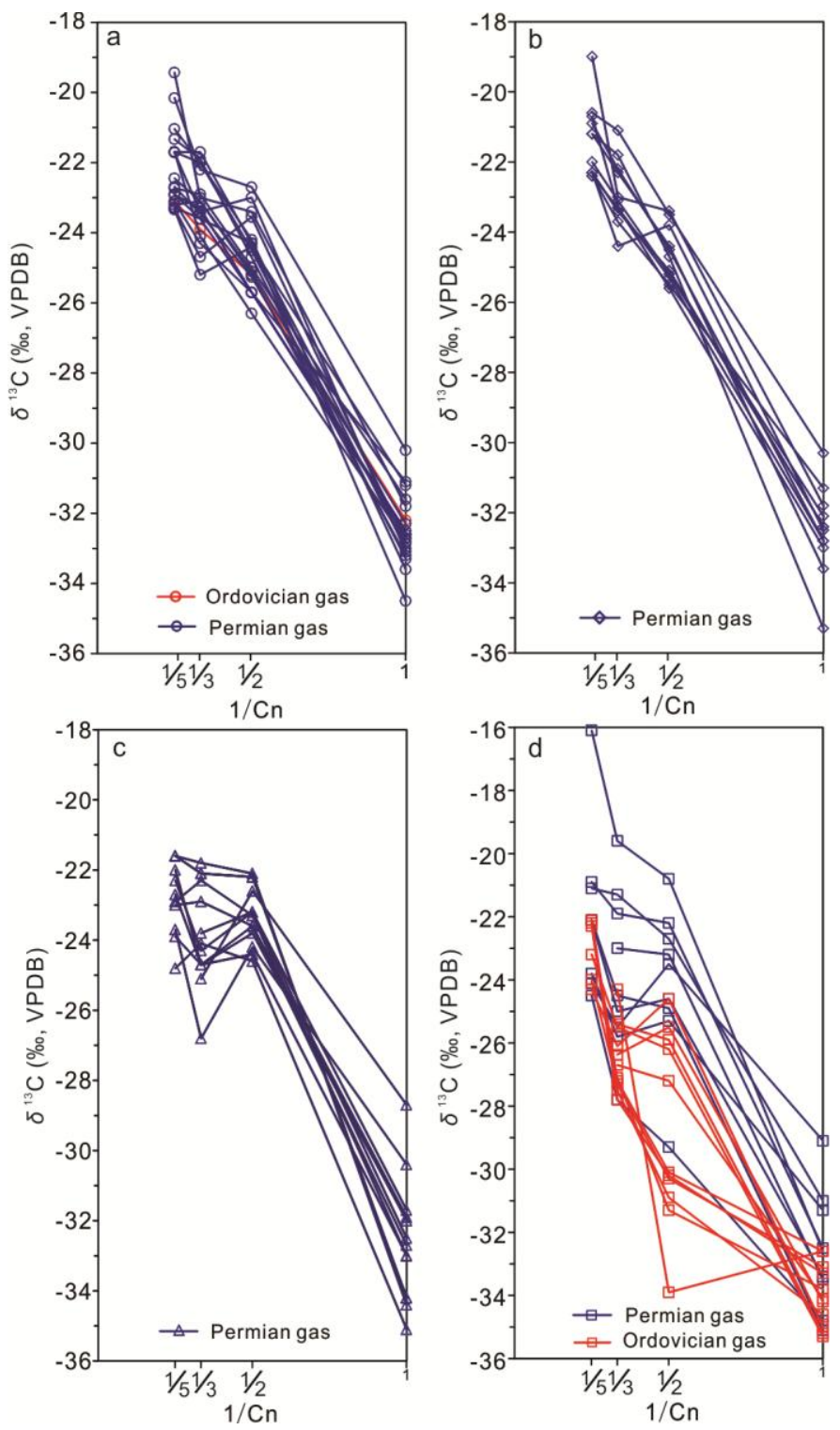

Fig.3 Stable carbon isotope values of alkane gases in Zizhou and other gas fields in the Ordos

Basin (a) Zizhou gas field; (b) Yulin gas field; (c) Sulige gas field; and (d) Jingbian gas field. (data sources: Dai et al., 1992, 2005; Hu et al., 2010; Yu et al., 2013; this paper) 

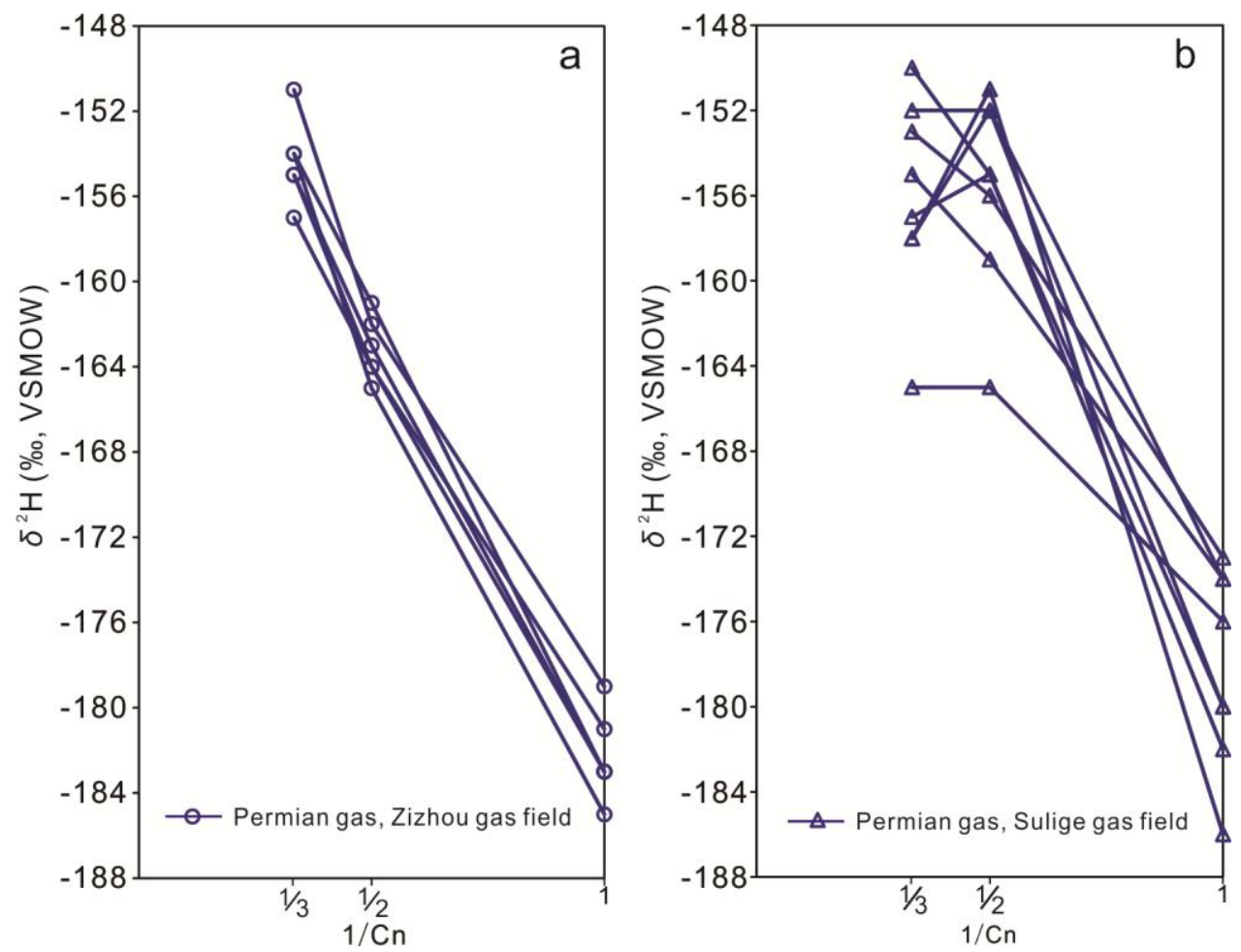

Fig. 4 Stable hydrogen isotope ratios of alkane gases in Zizhou and other gas fields in the Ordos Basin (data sources: Yu et al., 2013; this paper) 


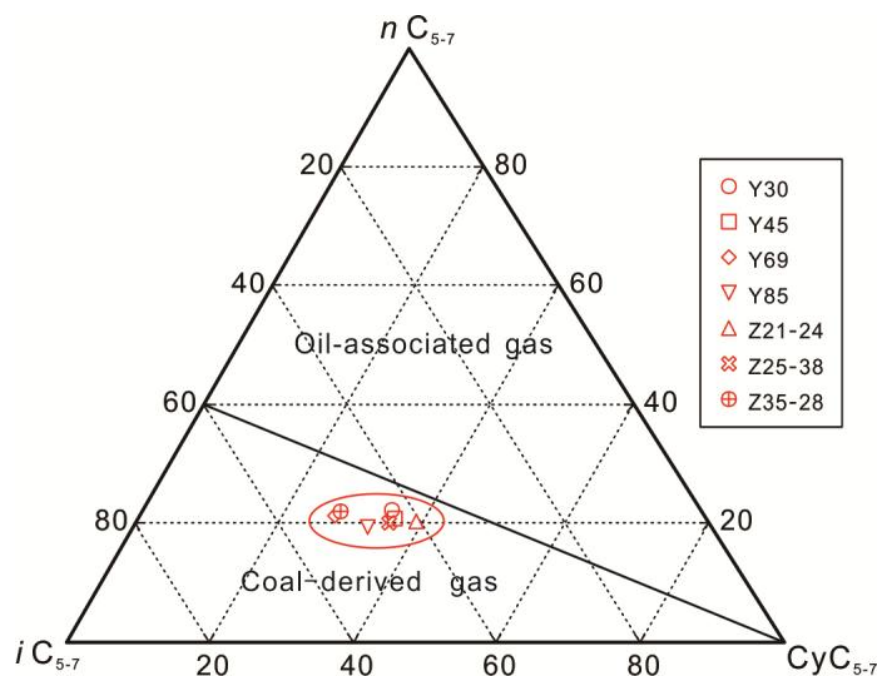

Fig. 5 Triangular plot of $\mathrm{C}_{5-7}$ light hydrocarbon composition for Zizhou gas field in the Ordos

Basin (diagram after Hu et al., 1990) 


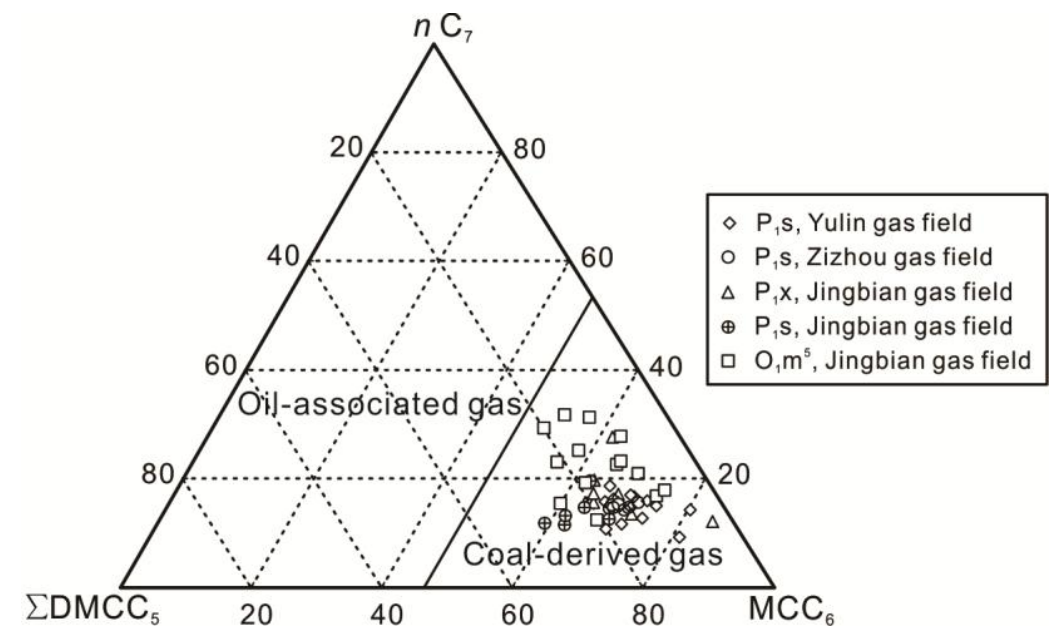

Fig. 6 Triangular plot of Paleozoic $C_{7}$ light hydrocarbon composition in the Ordos Basin

(diagram after Dai et al., 1992) (data sources: Hu et al., 2010; Hu and Zhang, 2011; this paper) 


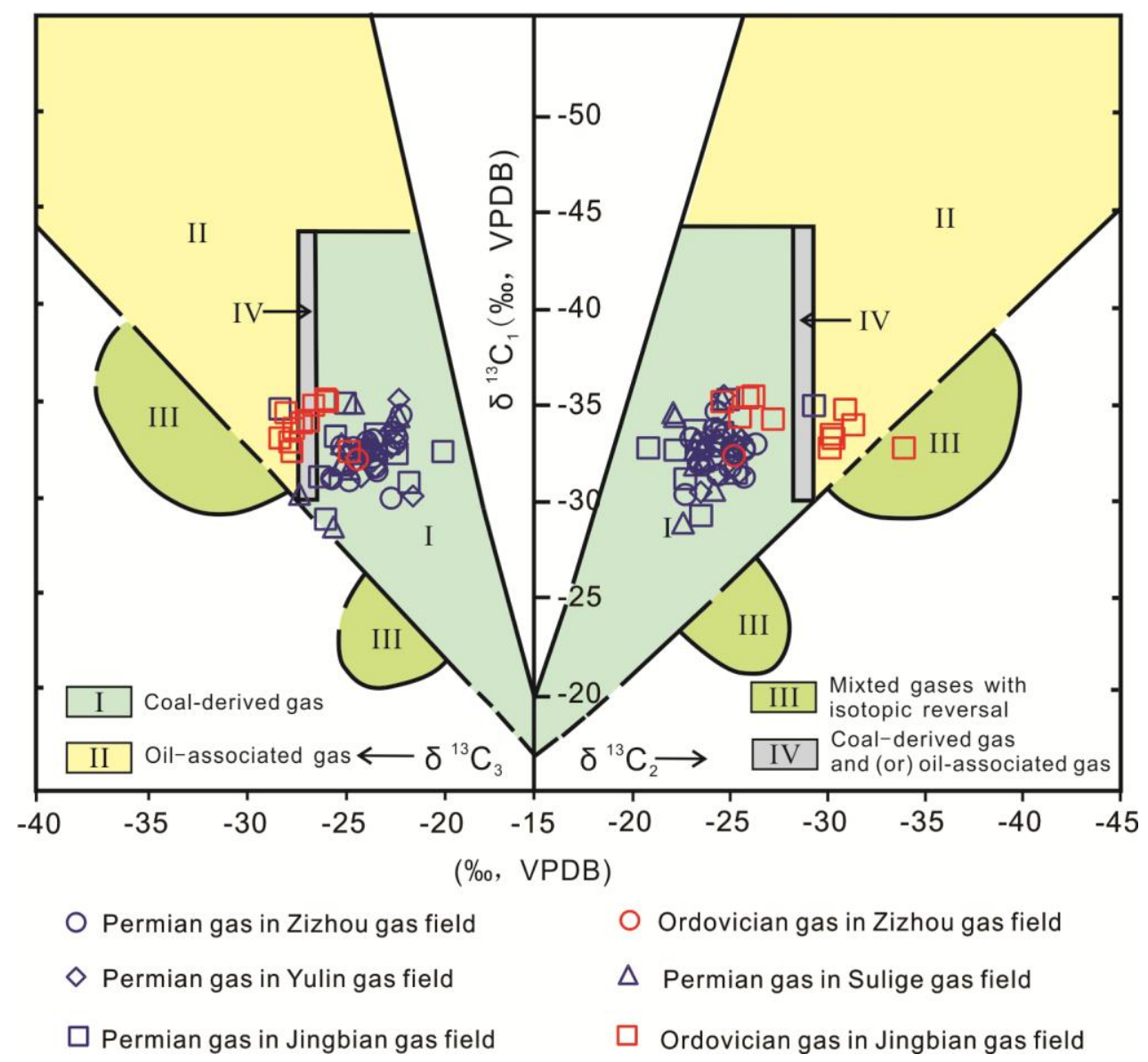

Fig. 7 Natural gas geneses identification based on $\delta{ }^{13} \mathrm{C}_{1}-\delta{ }^{13} \mathrm{C}_{2}-\delta{ }^{13} \mathrm{C}_{3}$ for Paleozoic gas fields in the Ordos Basin (diagram after Dai et al., 2014, same data as in Fig. 3) 


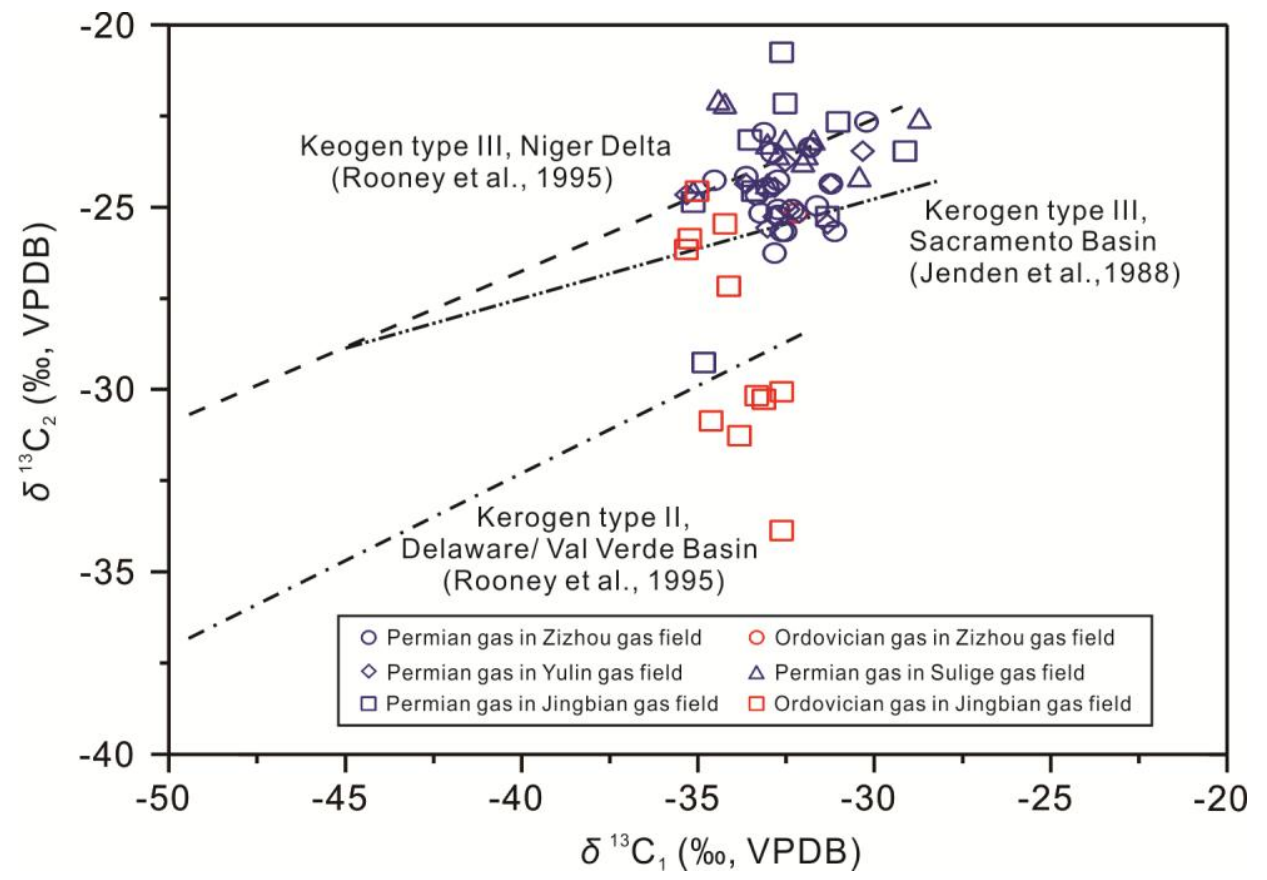

Fig. $8 \delta^{13} C_{1}-\delta{ }^{13} C_{2}$ regression lines for alkane gases in Paleozoic gas fields, Ordos Basin (same data as in Fig. 3) 


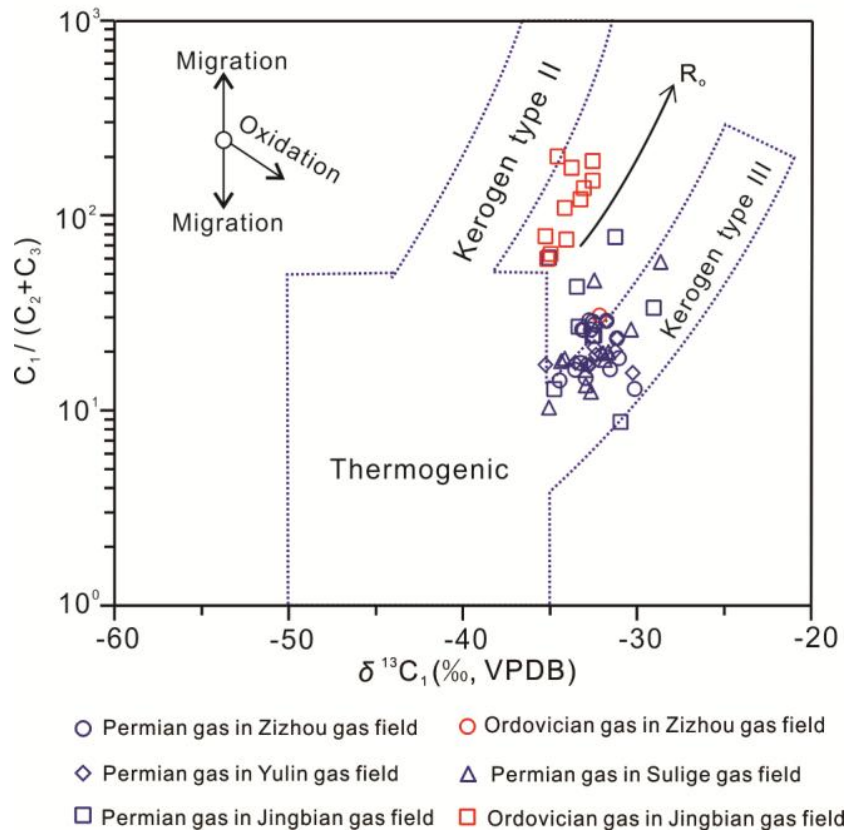

Fig. $9 \delta{ }^{13} \mathrm{C}_{1}-\mathrm{C}_{1} /\left(\mathrm{C}_{2}+\mathrm{C}_{3}\right)$ correlation for alkane gases in Paleozoic gas fields, Ordos Basin

(diagram after Whiticar, 1999 with the same data as in Fig. 3) 


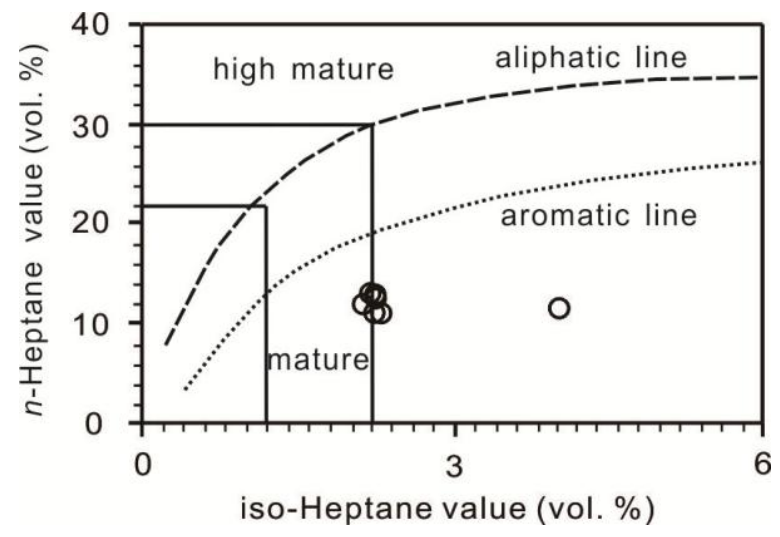

Fig.10 A plot of $n$-Heptane value (vol. \%) vs iso-Heptane value (vol. \%) of the gases reservoired in Zizhou gas field in the Ordos Basin (Plot after Thompson, 1983) 

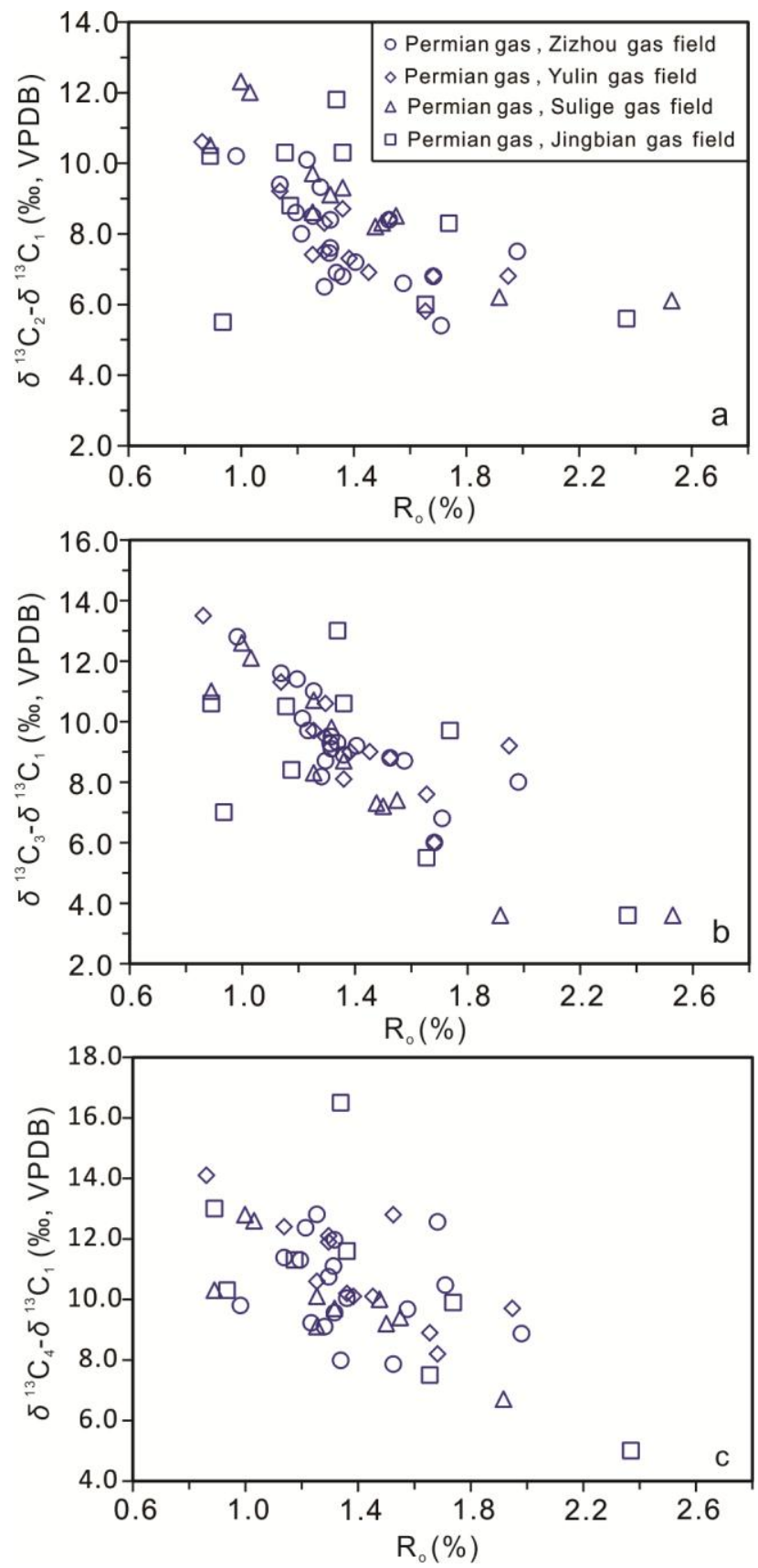

Fig.11 Correlation between natural gas maturity $\left(\mathbf{R}_{\mathbf{0}}\right)$ and carbon isotopic differences between heavy hydrocarbons and methane in Paleozoic gas fields, the Ordos Basin 


\section{Clean tables}

Table 1 Components and the stable carbon and hydrogen isotopes of the gases in the Zizhou gas field in the Ordos Basin

\begin{tabular}{|c|c|c|c|c|c|c|c|c|c|c|c|c|c|c|c|c|c|c|c|c|c|}
\hline \multirow{2}{*}{ Well } & \multirow{2}{*}{ Strata } & \multirow{2}{*}{ Depth（m) } & \multicolumn{7}{|c|}{ Gas components $(\%)$} & \multicolumn{4}{|c|}{$\delta^{13} \mathrm{C}(\%, \mathrm{VPDB})$} & \multicolumn{3}{|c|}{$\delta^{2} \mathrm{H}(\%$, VSMOW $)$} & \multirow{2}{*}{$\begin{array}{l}\mathrm{R}_{\mathrm{o}} \text {-Stahl } \\
(1975)\end{array}$} & \multirow{2}{*}{$\begin{array}{l}\mathrm{R}_{0} \text {-Dai } \\
(1989)\end{array}$} & \multirow{2}{*}{$\begin{array}{l}\mathrm{R}_{0} \text {-Shen } \\
(1991)\end{array}$} & \multirow{2}{*}{$\begin{array}{l}\mathrm{R}_{0}-\mathrm{Liu} \\
(1999)\end{array}$} & \multirow{2}{*}{ Reference } \\
\hline & & & $\mathrm{CH}_{4}$ & $\mathrm{C}_{2} \mathrm{H}_{6}$ & $\mathrm{C}_{3} \mathrm{H}_{6}$ & $\mathrm{C}_{4} \mathrm{H}_{10}$ & $\mathrm{C}_{1} / \mathrm{C}_{1-4}$ & $\mathrm{CO}_{2}$ & $\mathrm{~N}_{2}$ & $\mathrm{CH}_{4}$ & $\mathrm{C}_{2} \mathrm{H}_{6}$ & $\mathrm{C}_{3} \mathrm{H}_{6}$ & $\mathrm{C}_{4} \mathrm{H}_{10}$ & $\mathrm{CH}_{4}$ & $\mathrm{C}_{2} \mathrm{H}_{6}$ & $\mathrm{C}_{3} \mathrm{H}_{6}$ & & & & & \\
\hline $\mathrm{Z} 1$ & $\mathrm{O}_{1}$ & $2446.0-2449.0$ & 94.92 & 2.69 & 0.38 & 0.11 & 0.968 & 1.52 & 0.31 & -32.2 & -25.2 & -23.9 & -23.1 & & & & 0.50 & 1.43 & 1.18 & 1.31 & Dai et al.,1992 \\
\hline $\mathrm{Z} 4$ & $P_{1} t$ & $2356.0-2372.0$ & & & & & & & & -32.9 & -23.6 & -24.7 & -23.3 & & & & 0.45 & 1.28 & 0.98 & 1.22 & Dai, 2009 \\
\hline $\mathrm{Z} 5$ & $\mathrm{P}_{1} \mathrm{t}$ & 2383.0-2394.0 & & & & & & & & -32.7 & -24.3 & -23.6 & -22.9 & & & & 0.46 & 1.32 & 1.03 & 1.24 & Dai, 2009 \\
\hline Z16-19 & $\mathrm{P}_{1} \mathrm{~s}$ & 2712.5 & 91.53 & 5.22 & 1.16 & 0.39 & 0.931 & & & -34.5 & -24.3 & -21.7 & -21.7 & & & & 0.34 & 0.98 & 0.62 & 1.03 & \\
\hline $\mathrm{Z} 17-20$ & $\mathrm{P}_{1} \mathrm{~s}$ & 2644.5 & 91.55 & 5.07 & 1.13 & 0.40 & 0.933 & & & -33.0 & -24.5 & -22.0 & -21.7 & & & & 0.44 & 1.25 & 0.95 & 1.20 & \\
\hline Z19-22 & $\mathrm{P}_{1} \mathrm{~S}$ & 2635.0 & 93.00 & 4.43 & 0.84 & 0.31 & 0.943 & & & -33.3 & -24.7 & -21.9 & -21.3 & & & & 0.42 & 1.19 & 0.87 & 1.17 & \\
\hline Z21-24 & $\mathrm{P}_{1} \mathrm{~S}$ & & 94.22 & 3.12 & 0.48 & 0.15 & 0.962 & 1.58 & 0.32 & -32.7 & -25.1 & -23.2 & -22.2 & -183 & -163 & -155 & 0.46 & 1.32 & 1.03 & 1.24 & \\
\hline Z22-18 & $\mathrm{P}_{1} \mathrm{~s}$ & 2592.0 & 93.12 & 4.22 & 0.76 & 0.27 & 0.947 & & & -31.1 & -25.7 & -24.3 & -23.1 & & & & 0.60 & 1.71 & 1.62 & 1.46 & \\
\hline Z25-38 & $\mathrm{P}_{1} \mathrm{~S}$ & & 94.67 & 2.87 & 0.42 & 0.13 & 0.965 & 1.40 & 0.38 & -32.6 & -25.7 & -23.3 & -22.9 & -185 & -165 & -154 & 0.47 & 1.34 & 1.06 & 1.25 & \\
\hline Z26-26 & $\mathrm{P}_{1} \mathrm{~S}$ & 2505.0 & 91.63 & 4.60 & 0.99 & 0.37 & 0.939 & & & -31.6 & -25.0 & -22.9 & -22.7 & & & & 0.55 & 1.58 & 1.40 & 1.39 & \\
\hline Z28-43 & $\mathrm{P}_{1} \mathrm{~S}$ & 2330.0 & 90.44 & 5.42 & 1.54 & 0.65 & 0.922 & & & -30.2 & -22.7 & -22.2 & -20.2 & & & & 0.70 & 1.98 & 2.08 & 1.60 & \\
\hline Z35-28 & $\mathrm{P}_{1} \mathrm{~S}$ & & 94.81 & 2.97 & 0.44 & 0.13 & 0.964 & 1.20 & 0.37 & -32.5 & -25.7 & -23.6 & -23.3 & -181 & -164 & -157 & 0.48 & 1.36 & 1.09 & 1.27 & This paper \\
\hline Y30 & $\mathrm{P}_{1} \mathrm{~s}$ & & 94.10 & 3.14 & 0.48 & 0.15 & 0.961 & 1.62 & 0.38 & -33.1 & -23.0 & -23.4 & -21.7 & -183 & -161 & -154 & 0.43 & 1.23 & 0.92 & 1.19 & \\
\hline Y41-18 & $\mathrm{P}_{1} \mathrm{~S}$ & & 92.47 & 4.60 & 1.08 & 0.42 & 0.938 & 0.97 & 0.23 & -33.6 & -24.2 & -22.0 & -21.0 & & & & 0.40 & 1.14 & 0.80 & 1.13 & \\
\hline Y44-01 & $\mathrm{P}_{2} \mathrm{x}$ & & 94.41 & 3.81 & 0.19 & 0.24 & 0.957 & 0.50 & 0.75 & -31.2 & -24.4 & -25.2 & -23.3 & & & & 0.59 & 1.68 & 1.57 & 1.45 & \\
\hline Y44-03 & $\mathrm{P}_{1} \mathrm{~s}, \mathrm{C}_{2} \mathrm{~b}$ & & 94.27 & 3.09 & 0.16 & 0.14 & 0.965 & 1.93 & 0.33 & -31.8 & -23.4 & -23.0 & -19.4 & & & & 0.54 & 1.53 & 1.33 & 1.36 & \\
\hline Y45 & $\mathrm{P}_{1} \mathrm{~S}$ & & 94.17 & 3.12 & 0.48 & 0.16 & 0.962 & 1.58 & 0.36 & -33.2 & -25.2 & -23.1 & -22.5 & -183 & -164 & -155 & 0.43 & 1.21 & 0.89 & 1.18 & \\
\hline Y69 & $\mathrm{P}_{1} \mathrm{~S}$ & & 94.93 & 2.85 & 0.40 & 0.12 & 0.966 & 1.27 & 0.35 & -32.8 & -26.3 & -24.1 & -21.7 & -179 & -162 & -151 & 0.45 & 1.30 & 1.00 & 1.23 & \\
\hline Y80 & $\mathrm{P}_{1} \mathrm{~s}$ & $2607.0-2610.5$ & & & & & & & & -32.7 & -25.3 & -23.5 & -22.7 & & & & 0.46 & 1.31 & 1.02 & 1.24 & \\
\hline Y85 & $\mathrm{P}_{1} \mathrm{~s}, \mathrm{P}_{2} \mathrm{X}$ & & 93.83 & 2.83 & 0.39 & 0.12 & 0.966 & 1.22 & 1.48 & & & & & & & & & & & & \\
\hline P2 & $\mathrm{P}_{1} \mathrm{~s}$ & & 95.35 & 2.82 & 0.36 & 0.09 & 0.967 & 0.71 & 0.51 & -32.3 & -25.1 & -23.1 & -23.2 & & & & 0.49 & 1.41 & 1.15 & 1.29 & Dai, 2009 \\
\hline
\end{tabular}


Note: Vitrinite reflectance values $\left(\mathrm{R}_{\mathrm{o}} \%\right)$ were calculated according to different calibration equations according to Stahl and Carey, 1975, Dai and Qi, 1989, Shen et al., 1991, and Liu and Xu, 1999

Table 2

The maximum, minimum, and the averages values of the contents, carbon and hydrogen isotopes of the alkane gases in the Zizhou gas field, the Ordos Basin

\begin{tabular}{|c|c|c|c|c|c|c|c|c|c|c|c|c|c|}
\hline \multirow{2}{*}{$\begin{array}{l}\text { Gas components, } \\
\text { carbon, and hydrogen } \\
\text { isotopes }\end{array}$} & \multicolumn{6}{|c|}{ Components $(\%)$} & \multicolumn{4}{|c|}{$\delta^{13} \mathrm{C}(\%, \mathrm{VPDB})$} & \multicolumn{3}{|c|}{$\delta^{2} \mathrm{H}(\%, \mathrm{VSMOW})$} \\
\hline & $\mathrm{CH}_{4}$ & $\mathrm{C}_{2} \mathrm{H}_{6}$ & $\mathrm{C}_{3} \mathrm{H}_{6}$ & $\mathrm{C}_{4} \mathrm{H}_{10}$ & $\mathrm{CO}_{2}$ & $\mathrm{~N}_{2}$ & $\mathrm{CH}_{4}$ & $\mathrm{C}_{2} \mathrm{H}_{6}$ & $\mathrm{C}_{3} \mathrm{H}_{6}$ & $\mathrm{C}_{4} \mathrm{H}_{10}$ & $\mathrm{CH}_{4}$ & $\mathrm{C}_{2} \mathrm{H}_{6}$ & $\mathrm{C}_{3} \mathrm{H}_{6}$ \\
\hline Maximum value & 95.35 & 5.42 & 1.54 & 0.65 & 1.93 & 1.48 & -30.2 & -22.7 & -21.7 & -19.4 & -179 & -161 & -151 \\
\hline Mininum value & 90.44 & 2.69 & 0.16 & 0.09 & 0.50 & 0.23 & -34.5 & -26.3 & -25.2 & -23.3 & -185 & -165 & -157 \\
\hline Average value & 93.52 & 3.72 & 0.65 & 0.24 & 1.29 & 0.48 & -32.5 & -24.7 & -23.2 & -22.2 & -182 & -163 & -154 \\
\hline
\end{tabular}


Table 3

Geochemical data of the components and the carbon and hydrogen isotopes of alkane gases in the Yulin gas field, Ordos Basin (Hu et al., 2010)

\begin{tabular}{|c|c|c|c|c|c|c|c|c|c|c|c|c|c|c|c|c|}
\hline \multirow{2}{*}{ Well } & \multirow{2}{*}{ Strata } & \multicolumn{5}{|c|}{ Component $(\%)$} & \multicolumn{6}{|c|}{$\delta^{13} \mathrm{C}(\%, \mathrm{VPDB})$} & \multirow{2}{*}{$\begin{array}{l}\mathrm{R}_{\mathrm{o}} \text {-Stahl } \\
(1975)\end{array}$} & \multirow{2}{*}{$\begin{array}{l}\text { R}_{0} \text {-Dai } \\
(1989)\end{array}$} & \multirow{2}{*}{$\begin{array}{l}\mathrm{R}_{\mathrm{o}} \text {-Shen } \\
(1991)\end{array}$} & \multirow{2}{*}{$\begin{array}{l}\mathrm{R}_{\mathrm{o}} \text {-Liu } \\
\text { (1999) }\end{array}$} \\
\hline & & $\mathrm{CH}_{4}$ & $\mathrm{C}_{2} \mathrm{H}_{6}$ & $\mathrm{C}_{3} \mathrm{H}_{6}$ & $\mathrm{C}_{4} \mathrm{H}_{10}$ & $\mathrm{C}_{1} / \mathrm{C}_{1-4}$ & $\mathrm{CO}_{2}$ & $\mathrm{~N}_{2}$ & $\mathrm{CH}_{4}$ & $\mathrm{C}_{2} \mathrm{H}_{6}$ & $\mathrm{C}_{3} \mathrm{H}_{6}$ & $\mathrm{C}_{4} \mathrm{H}_{10}$ & & & & \\
\hline Yu32-15 & $\mathrm{P}_{1} \mathrm{~s}$ & 92.22 & 4.20 & 1.09 & 0.43 & 0.942 & 1.72 & 0.18 & -33.0 & -25.6 & -23.3 & -22.4 & 0.44 & 1.25 & 0.95 & 1.20 \\
\hline Yu34-15 & $\mathrm{P}_{1} \mathrm{~s}$ & 92.63 & 4.36 & 1.00 & 0.35 & 0.942 & 1.27 & 0.23 & -35.3 & -24.7 & -21.8 & -21.2 & 0.30 & 0.86 & 0.51 & 0.95 \\
\hline Yu36-9 & $\mathrm{P}_{1} \mathrm{~s}$ & 93.97 & 4.05 & 0.78 & 0.23 & 0.949 & 0.64 & 0.24 & -32.4 & -25.1 & -23.4 & -22.3 & 0.48 & 1.38 & 1.11 & 1.28 \\
\hline Yu41-01 & $\mathrm{P}_{1} \mathrm{~s}$ & 94.41 & 3.81 & 0.19 & 0.24 & 0.957 & 0.50 & 0.75 & -31.2 & -24.4 & -25.2 & -23.0 & 0.59 & 1.68 & 1.53 & 1.45 \\
\hline Yu42-6 & $\mathrm{P}_{1} \mathrm{~s}$ & 92.75 & 3.69 & 0.85 & 0.34 & 0.950 & 2.00 & 0.24 & -31.3 & -25.5 & -23.7 & -22.4 & 0.58 & 1.66 & 1.49 & 1.43 \\
\hline Yu44-03 & $\mathrm{P}_{1} \mathrm{~s}$ & 94.27 & 3.09 & 0.16 & 0.14 & 0.965 & 1.93 & 0.33 & -31.8 & -23.4 & -23.0 & -19.0 & 0.54 & 1.53 & 1.31 & 1.36 \\
\hline Yu44-12 & $\mathrm{P}_{1} \mathrm{~s}$ & 93.26 & 4.01 & 0.74 & 0.24 & 0.949 & 1.37 & 0.27 & -32.1 & -25.2 & -23.1 & -22.0 & 0.51 & 1.45 & 1.21 & 1.32 \\
\hline Yu46-9A & $\mathrm{P}_{1} \mathrm{~s}$ & 92.55 & 4.44 & 0.92 & 0.30 & 0.942 & 1.39 & 0.26 & -32.8 & -25.3 & -23.3 & -20.7 & 0.45 & 1.30 & 1.00 & 1.23 \\
\hline Yu47-9B & $\mathrm{P}_{1} \mathrm{~s}$ & 92.29 & 4.82 & 1.06 & 0.36 & 0.937 & 0.97 & 0.32 & -30.3 & -23.5 & -21.1 & -20.6 & 0.69 & 1.95 & 1.95 & 1.59 \\
\hline Yu50-8 & $\mathrm{P}_{1} \mathrm{~s}$ & 92.68 & 4.31 & 0.93 & 0.33 & 0.943 & 1.32 & 0.26 & -33.6 & -24.4 & -22.3 & -21.2 & 0.40 & 1.14 & 0.81 & 1.13 \\
\hline Shan209 & $\mathrm{P}_{1} \mathrm{~s}$ & 92.26 & 4.41 & 1.01 & 0.37 & 0.941 & 1.51 & 0.26 & -32.8 & -24.5 & -22.2 & -20.9 & 0.45 & 1.30 & 1.00 & 1.23 \\
\hline Shan217 & $\mathrm{P}_{1} \mathrm{~s}$ & 93.36 & 3.75 & 0.64 & 0.20 & 0.953 & 1.73 & 0.25 & -32.5 & -23.8 & -24.4 & -22.3 & 0.48 & 1.36 & 1.08 & 1.27 \\
\hline
\end{tabular}


Table 4

Geochemical data of the components and the carbon and hydrogen isotopes of alkane gases in the Sulige gas field, Ordos Basin

\begin{tabular}{|c|c|c|c|c|c|c|c|c|c|c|c|c|c|c|c|c|c|c|c|c|}
\hline \multirow{2}{*}{ Well } & \multirow{2}{*}{ Strata } & \multicolumn{7}{|c|}{ Component $(\%)$} & \multicolumn{4}{|c|}{$\delta^{13} \mathrm{C}(\%, \mathrm{VPDB})$} & \multicolumn{3}{|c|}{$\delta^{2} \mathrm{H}(\%$, VSMOW $)$} & \multirow{2}{*}{$\begin{array}{l}\mathrm{R}_{\mathrm{o}} \text {-Stahl } \\
(1975)\end{array}$} & \multirow{2}{*}{$\begin{array}{l}\text { Ro }_{0} \text {-Dai } \\
(1989)\end{array}$} & \multirow{2}{*}{$\begin{array}{l}\mathrm{R}_{\mathrm{o}} \text {-Shen } \\
\text { (1991) }\end{array}$} & \multirow{2}{*}{$\begin{array}{l}\mathrm{R}_{\mathrm{o}} \text {-Liu } \\
\text { (1999) }\end{array}$} & \multirow{2}{*}{ Reference } \\
\hline & & $\mathrm{CH}_{4}$ & $\mathrm{C}_{2} \mathrm{H}_{6}$ & $\mathrm{C}_{3} \mathrm{H}_{6}$ & $\mathrm{C}_{4} \mathrm{H}_{10}$ & $\mathrm{C}_{1} / \mathrm{C}_{1-4}$ & $\mathrm{CO}_{2}$ & $\mathrm{~N}_{2}$ & $\mathrm{CH}_{4}$ & $\mathrm{C}_{2} \mathrm{H}_{6}$ & $\mathrm{C}_{3} \mathrm{H}_{6}$ & $\mathrm{C}_{4} \mathrm{H}_{10}$ & $\mathrm{CH}_{4}$ & $\mathrm{C}_{2} \mathrm{H}_{6}$ & $\mathrm{C}_{3} \mathrm{H}_{6}$ & & & & & \\
\hline Su55 & $\mathrm{P}_{1} \mathrm{x}$ & 88.96 & 7.07 & 1.47 & 0.49 & 0.908 & 0.68 & 0.88 & -35.1 & -24.6 & -24.1 & -24.8 & -186 & -151 & -158 & 0.31 & 0.89 & 0.54 & 0.97 & \multirow{8}{*}{$\begin{array}{l}\text { Yu et al, } \\
2013\end{array}$} \\
\hline Su136 & $\mathrm{P}_{1} \mathrm{~s}, \mathrm{P}_{1} \mathrm{x}$ & 90.20 & 1.40 & 0.15 & 0.03 & 0.983 & 0.00 & 8.06 & -28.7 & -22.6 & -25.1 & & -173 & -156 & -153 & 0.89 & 2.53 & 2.98 & 1.87 & \\
\hline Su139 & $\mathrm{P}_{1} \mathrm{~s}, \mathrm{P}_{1} \mathrm{x}$ & 93.16 & 3.05 & 0.51 & 0.14 & 0.962 & 1.31 & 1.45 & -30.4 & -24.2 & -26.8 & -23.7 & -176 & -165 & -165 & 0.67 & 1.92 & 1.90 & 1.57 & \\
\hline Su11-18-36 & $\mathrm{P}_{1} \mathrm{x}$ & 90.16 & 5.50 & 1.15 & 0.42 & 0.927 & 1.47 & 0.94 & -33.0 & -23.3 & -22.3 & -22.9 & -180 & -152 & -152 & 0.44 & 1.25 & 0.95 & 1.20 & \\
\hline Su120-42-84 & $\mathrm{P}_{1} \mathrm{~s}, \mathrm{P}_{1} \mathrm{x}$ & 91.15 & 4.19 & 0.79 & 0.29 & 0.945 & 2.25 & 1.04 & -31.9 & -23.6 & -24.7 & -22.7 & -174 & -152 & -158 & 0.53 & 1.50 & 1.27 & 1.35 & \\
\hline $\mathrm{Su} 48-2-86$ & $\mathrm{P}_{1} \mathrm{~s}$ & 92.85 & 4.00 & 0.63 & 0.21 & 0.950 & 1.44 & 0.57 & -31.7 & -23.2 & -24.3 & -22.3 & -174 & -159 & -155 & 0.54 & 1.55 & 1.34 & 1.37 & \\
\hline Su76-1-4 & $\mathrm{P}_{1} \mathrm{~s}$ & 90.38 & 6.03 & 1.18 & 0.43 & 0.922 & 0.82 & 0.71 & -32.7 & -23.6 & -22.9 & -23.0 & -182 & -155 & -150 & 0.46 & 1.32 & 1.03 & 1.24 & \\
\hline S14-0-31 & $\mathrm{P}_{1} \mathrm{~s}, \mathrm{P}_{1} \mathrm{x}$ & 93.00 & 4.05 & 0.65 & 0.21 & 0.950 & 1.20 & 0.59 & -32.0 & -23.8 & -24.7 & -22.0 & -180 & -155 & -157 & 0.52 & 1.48 & 1.24 & 1.33 & \\
\hline Su1 & $\mathrm{P}_{1} \mathrm{x}$ & 92.24 & 4.16 & 0.81 & 0.32 & 0.946 & 1.70 & 0.56 & -34.2 & -22.2 & -22.1 & -21.6 & & & & 0.36 & 1.03 & 0.69 & 1.06 & \multirow{4}{*}{$\begin{array}{l}\text { Dai et al., } \\
2005\end{array}$} \\
\hline Su1 & $\mathrm{P}_{1} \mathrm{~s}$ & 92.47 & 4.26 & 0.86 & 0.36 & 0.944 & 1.25 & 0.51 & -34.4 & -22.1 & -21.8 & -21.6 & & & & 0.35 & 1.00 & 0.65 & 1.04 & \\
\hline Su 14 & $P_{1} x$ & 96.37 & 1.66 & 0.40 & 0.22 & 0.977 & 1.35 & 0.00 & -32.5 & -23.2 & -23.8 & & & & & 0.48 & 1.36 & 1.08 & 1.27 & \\
\hline Su20 & $P_{1} x$ & 92.42 & 4.82 & 0.87 & 0.31 & 0.939 & 0.66 & 0.78 & -33.0 & -24.4 & -24.7 & -23.9 & & & & 0.44 & 1.25 & 0.95 & 1.20 & \\
\hline
\end{tabular}


Table 5

Geochemical data of the components and the carbon and hydrogen isotopes of alkane gases in the Jingbian gas field, Ordos Basin (Dai et al., 2005)

\begin{tabular}{|c|c|c|c|c|c|c|c|c|c|c|c|c|c|c|c|c|c|c|c|c|}
\hline \multirow{2}{*}{ Well } & \multirow{2}{*}{ Strata } & \multirow{2}{*}{ Depth $(\mathrm{m})$} & \multicolumn{7}{|c|}{ Component $(\%)$} & \multicolumn{4}{|c|}{$\delta^{13} \mathrm{C}(\%, \mathrm{VPDB})$} & \multicolumn{3}{|c|}{$\delta^{2} \mathrm{H}(\%, \mathrm{VSMOW})$} & \multirow{2}{*}{$\begin{array}{l}\mathrm{R}_{\mathrm{o}}-\text { Stahl } \\
(1975)\end{array}$} & \multirow{2}{*}{$\begin{array}{l}\mathrm{R}_{\mathrm{o}} \text {-Dai } \\
(1989)\end{array}$} & \multirow{2}{*}{$\begin{array}{l}\mathrm{R}_{\mathrm{o}} \text {-Shen } \\
\text { (1991) }\end{array}$} & \multirow{2}{*}{$\begin{array}{l}\mathrm{R}_{\mathrm{o}} \text {-Liu } \\
(1999)\end{array}$} \\
\hline & & & $\mathrm{CH}_{4}$ & $\mathrm{C}_{2} \mathrm{H}_{6}$ & $\mathrm{C}_{3} \mathrm{H}_{6}$ & $\mathrm{C}_{4} \mathrm{H}_{10}$ & $\mathrm{C}_{1} / \mathrm{C}_{1-4}$ & $\mathrm{CO}_{2}$ & $\mathrm{~N}_{2}$ & $\mathrm{CH}_{4}$ & $\mathrm{C}_{2} \mathrm{H}_{6}$ & $\mathrm{C}_{3} \mathrm{H}_{6}$ & $\mathrm{C}_{4} \mathrm{H}_{10}$ & $\mathrm{CH}_{4}$ & $\mathrm{C}_{2} \mathrm{H}_{6}$ & $\mathrm{C}_{3} \mathrm{H}_{6}$ & & & & \\
\hline Shan 16 & $\mathrm{P}_{1} \mathrm{~s}$ & $2936.0-2940.0$ & 85.84 & 0.99 & 0.11 & 0.02 & 0.987 & 0.90 & 10.86 & -31.3 & -25.3 & -25.8 & -23.8 & & & & 0.58 & 1.66 & 1.49 & 1.43 \\
\hline Shan19 & $\mathrm{P}_{1} \mathrm{x}$ & $3171.0-3176.0$ & 94.91 & 1.41 & 0.14 & 0.04 & 0.984 & 1.29 & 1.90 & -35.1 & -24.9 & -24.5 & -22.1 & & & & 0.31 & 0.89 & 0.54 & 0.97 \\
\hline Shan26 & $\mathrm{P}_{1} \mathrm{t}$ & $3407.4-3411.4$ & 87.22 & 1.84 & 0.17 & 0.04 & 0.977 & 7.05 & 3.03 & -33.5 & -23.2 & -23.0 & & & & & 0.40 & 1.16 & 0.83 & 1.14 \\
\hline Shan41 & $\mathrm{P}_{1} \mathrm{~S}$ & $3100.3-3104.0$ & 95.02 & 3.06 & 0.45 & 0.10 & 0.963 & & 1.15 & -33.4 & -24.6 & -25.0 & -22.1 & & & & 0.41 & 1.18 & 0.85 & 1.15 \\
\hline Shan46 & $\mathrm{P}_{1} \mathrm{~s}$ & $3214.0-3217.6$ & 85.80 & 7.67 & 2.07 & 0.87 & 0.890 & 1.20 & 1.33 & -31.0 & -22.7 & -21.3 & -21.1 & & & & 0.61 & 1.74 & 1.62 & 1.48 \\
\hline Shan65 & $\mathrm{P}_{1} \mathrm{x}$ & $3149.0-3151.0$ & 95.74 & 2.54 & 0.29 & 0.07 & 0.971 & 0.13 & 1.10 & -29.1 & -23.5 & -25.5 & -24.1 & & & & 0.83 & 2.37 & 2.68 & 1.80 \\
\hline Shan67 & $\mathrm{P}_{1} \mathrm{~s}$ & $3618.5-3623.0$ & 94.36 & 3.39 & 0.47 & 0.16 & 0.959 & 0.83 & 0.55 & -32.5 & -22.2 & -21.9 & -20.9 & & & & 0.48 & 1.36 & 1.08 & 1.27 \\
\hline Shan68 & $\mathrm{P}_{1} \mathrm{~s}$ & $3535.0-3540.0$ & 90.97 & 5.91 & 1.11 & 0.41 & 0.924 & 0.11 & 4.06 & -34.8 & -29.3 & -27.8 & -24.5 & & & & 0.33 & 0.94 & 0.59 & 1.00 \\
\hline Shan83 & $\mathrm{P}_{1} \mathrm{~s}$ & $2939.0-2945.0$ & 93.32 & 3.39 & 0.45 & 0.24 & 0.958 & 0.80 & 5.70 & -32.6 & -20.8 & -19.6 & -16.1 & & & & 0.47 & 1.34 & 1.05 & 1.25 \\
\hline L2 & $\mathrm{O}_{1} \mathrm{~m}^{5}$ & $3190.0-3195.0$ & 95.34 & 1.40 & 0.18 & 0.05 & 0.983 & 2.62 & 0.39 & -35.2 & -25.9 & -25.4 & & & & & & & & \\
\hline $\mathrm{SC} 1$ & $\mathrm{O}_{1} \mathrm{~m}^{5}$ & $3441.0-3471.0$ & 96.36 & 1.17 & 0.10 & 0.02 & 0.987 & 1.47 & 1.27 & -34.1 & -27.2 & -26.7 & & & & & & & & \\
\hline Shan2 & $\mathrm{O}_{1} \mathrm{~m}^{5}$ & 3364.4-3369.4 & 96.09 & 1.09 & 0.13 & 0.04 & 0.987 & 2.60 & & -35.30 & -26.2 & -25.5 & -23.2 & & & & & & & \\
\hline Shan5 & $\mathrm{O}_{1} \mathrm{~m}^{5}$ & $3451.0-3550.0$ & 97.25 & 0.49 & 0.06 & 0.02 & 0.994 & 1.65 & 0.33 & -33.8 & -31.3 & -27.1 & & & & & & & & \\
\hline Shan 12 & $\mathrm{O}_{1} \mathrm{~m}^{5}$ & $3638.0-3700.0$ & 96.79 & 0.78 & 0.10 & 0.02 & 0.991 & 1.65 & 0.63 & -34.2 & -25.5 & -26.4 & & & & & & & & \\
\hline Shan 17 & $\mathrm{O}_{1} \mathrm{~m}^{5}$ & $3176.9-3181.0$ & 93.89 & 0.69 & 0.08 & 0.02 & 0.992 & 4.55 & 0.62 & -33.3 & -30.2 & -27.8 & -22.3 & & & & & & & \\
\hline Shan20 & $\mathrm{O}_{1} \mathrm{~m}^{5}$ & $3522.0-3524.0$ & 93.10 & 0.30 & 0.16 & 0.03 & 0.995 & 0.55 & 1.02 & -34.6 & -30.9 & -27.5 & -22.1 & & & & & & & \\
\hline Shan21 & $\mathrm{O}_{1} \mathrm{~m}^{5}$ & $3198.0-3203.0$ & 95.92 & 1.33 & 0.17 & 0.05 & 0.984 & 2.36 & 0.11 & -35.0 & -24.6 & -26.1 & -24.3 & & & & & & & \\
\hline Shan 102 & $\mathrm{O}_{1} \mathrm{~m}^{5}$ & $3370.35-3423$ & 95.94 & 0.46 & 0.04 & & 0.995 & 1.02 & 2.45 & -32.6 & -33.9 & -24.3 & & & & & & & & \\
\hline
\end{tabular}




\begin{tabular}{llllllllllllll}
\hline Shan154 & $\mathrm{O}_{1} \mathrm{~m}^{5}$ & $3154.0-3164.0$ & 94.35 & 0.55 & 0.07 & 0.02 & 0.993 & 3.95 & 1.06 & -32.6 & -30.1 & -27.2 & -22.2 \\
Shan155 & $\mathrm{O}_{1} \mathrm{~m}^{5}$ & $3217.3-3229.6$ & 93.15 & 0.63 & 0.04 & & 0.993 & 3.51 & 2.53 & -33.1 & -30.3 & -27.3 & -24.0
\end{tabular}

Table 6

Light hydrocarbon parameters of the gases in the Zizhou gas field, Ordos Basin

\begin{tabular}{|c|c|c|c|c|c|c|c|c|}
\hline & $\mathrm{C}_{5-7} n$-alkanes/ & $\mathrm{C}_{5-7} i$-alkanes/ & $\mathrm{C}_{5-7}$ Cyclanes/ & $i$ so-Heptane vale ${ }^{\mathrm{a}}$ & Heptane value ${ }^{\mathrm{b}}$ & $n \mathrm{C}_{7}^{\mathrm{c}}$ & $\mathrm{MCC}_{6}{ }^{\mathrm{d}}$ & $\Sigma \mathrm{DMCC}_{5}{ }^{\mathrm{e}}$ \\
\hline & $\Sigma \mathrm{C}_{5-7}(\%)$ & $\Sigma \mathrm{C}_{5-7}(\%)$ & $\Sigma \mathrm{C}_{5-7}(\%)$ & $(\mathrm{I}, \%)$ & $(\mathrm{H}, \%)$ & $(\%)$ & $(\%)$ & $(\%)$ \\
\hline Y30 & 22.5 & 43.3 & 34.8 & 2.1 & 11.8 & 15.3 & 67.8 & 16.9 \\
\hline Y45 & 21.1 & 43.7 & 35.9 & 2.2 & 12.8 & 14.8 & 70.5 & 14.7 \\
\hline Y69 & 21.6 & 51.7 & 27.3 & 2.3 & 10.9 & 14.7 & 67.6 & 17.6 \\
\hline Y85 & 19.8 & 48.1 & 32.9 & 4.0 & 11.4 & 15.7 & 71.6 & 12.7 \\
\hline Z21-24 & 20.6 & 40.9 & 39.3 & 2.2 & 12.9 & 15.4 & 68.8 & 15.9 \\
\hline Z25-38 & 20.4 & 44.8 & 35.5 & 2.3 & 12.4 & 14.4 & 70.0 & 15.6 \\
\hline Z35-28 & 22.3 & 50.4 & 27.8 & 2.2 & 11.0 & 14.9 & 68.2 & 16.9 \\
\hline
\end{tabular}

${ }^{\mathrm{a}} \mathrm{I}(\%)=(2 \mathrm{MH}+3 \mathrm{MH}) /(\mathrm{t}$ 1, $2 \mathrm{DMCP}+\mathrm{cl}, 3 \mathrm{DMCP}+\mathrm{t}$ 1, $3 \mathrm{DMCP}) ; \mathrm{P} 3=2,2 \mathrm{DMP}+2,4 \mathrm{DMP}+3,3 \mathrm{DMP}+2,3 \mathrm{DMP}+3 \mathrm{EP}$

${ }^{\mathrm{b}} \mathrm{H}(\%)=n \mathrm{C}_{7} \times 100 /\left(\mathrm{CH}+2 \mathrm{MH}+2,3 \mathrm{DMP}+1,1 \mathrm{DMCP}+3 \mathrm{MH}+\mathrm{c} 1,3 \mathrm{DMCP}+\mathrm{t} 1,3 \mathrm{DMCP}+\mathrm{t} 1,2 \mathrm{DMCP}+3 \mathrm{EP}, 2,2,4 \mathrm{TMP}+n \mathrm{C}_{7}+\mathrm{MCH}\right) ;$

${ }^{\mathrm{c}} n \mathrm{C}_{7} \%=n \mathrm{C}_{7} \times 100 /\left(n \mathrm{C}_{7}+\mathrm{MCC}_{6}+\Sigma \mathrm{MCC}_{5}\right)$;

${ }^{\mathrm{d}} \mathrm{MCC}_{6} \%=\mathrm{MCC}_{6} \times 100 /\left(n \mathrm{C}_{7}+\mathrm{MCC}_{6}+\Sigma \mathrm{MCC}_{5}\right)$;

${ }^{\mathrm{e}} \Sigma \mathrm{MCC}_{5} \%=\Sigma \mathrm{MCC}_{5} \times 100 /\left(n \mathrm{C}_{7}+\mathrm{MCC}_{6}+\Sigma \mathrm{MCC}_{5}\right)$ 